Cochrane Database of Systematic Reviews

\title{
Debridement of diabetic foot ulcers (Review)
}

Edwards J, Stapley S

Edwards J, Stapley S.

Debridement of diabetic foot ulcers.

Cochrane Database of Systematic Reviews 2010, Issue 1. Art. No.: CD003556.

DOI: 10.1002/14651858.CD003556.pub2. 
TABLE OF CONTENTS

HEADER 1

ABSTRACT

PLAIN LANGUAGE SUMMARY

BACKGROUND

OBJECTIVES

METHODS

RESULTS

Figure 1.

Figure 2.

DISCUSSION

AUTHORS' CONCLUSIONS

ACKNOWLEDGEMENTS

REFERENCES

CHARACTERISTICS OF STUDIES

DATA AND ANALYSES

Analysis 1.1. Comparison 1 Surgical debridement compared with conventional nonsurgical management, Outcome 1 Number of ulcers completely healed.

Analysis 1.2. Comparison 1 Surgical debridement compared with conventional nonsurgical management, Outcome 2 Time to complete healing (days).

Analysis 1.3. Comparison 1 Surgical debridement compared with conventional nonsurgical management, Outcome 3 Recurrence rates.

Analysis 1.4. Comparison 1 Surgical debridement compared with conventional nonsurgical management, Outcome 4 Number of complications - Number of adverse events reported.

Analysis 2.1. Comparison 2 Larvae compared with Hydrogel, Outcome 1 Number of ulcers completely healed.

Analysis 2.2. Comparison 2 Larvae compared with Hydrogel, Outcome 2 Reduction of wound area by more than $50 \%$. ...........

Analysis 3.1. Comparison 3 Hydrogel compared with gauze or good wound care (gwc), Outcome 1 Number of ulcers completely healed.

Analysis 3.2. Comparison 3 Hydrogel compared with gauze or good wound care (gwc), Outcome 2 Number of complications number of adverse events reported.

Analysis 3.3. Comparison 3 Hydrogel compared with gauze or good wound care (gwc), Outcome 3 Quality of life / increase in pain.

ADDITIONAL TABLES

APPENDICES

FEEDBACK

WHAT'S NEW

HISTORY

CONTRIBUTIONS OF AUTHORS

DECLARATIONS OF INTEREST

SOURCES OF SUPPORT

INDEX TERMS 
[Intervention Review]

\section{Debridement of diabetic foot ulcers}

Jude Edwards ${ }^{1}$, Sally Stapley ${ }^{2}$

1Department of Health and Social Care, Trafford College, Altrincham, UK. ${ }^{2}$ School of Health and Social Care, Teesside University, Middlesbrough, UK

Contact address: Jude Edwards, Department of Health and Social Care, Trafford College, Manchester Road, West Timperley, Altrincham, Cheshire,WA14 5PQ, UK. judeedwards@btinternet.com, jedwards@stcoll.ac.uk.

Editorial group: Cochrane Wounds Group.

Publication status and date: Edited (no change to conclusions), published in Issue 1, 2012.

Citation: Edwards J, Stapley S. Debridement of diabetic foot ulcers. Cochrane Database of Systematic Reviews 2010, Issue 1. Art. No.: CD003556. DOI: 10.1002/14651858.CD003556.pub2.

Copyright @ 2012 The Cochrane Collaboration. Published by John Wiley \& Sons, Ltd.

\section{A B S T R A C T}

\section{Background}

Foot ulceration is thought to affect $15 \%$ of people with diabetes at some time in their lives. Debridement is widely regarded as an effective intervention to speed up ulcer healing. The most effective method is unclear.

\section{Objectives}

To assess the effects of debridement interventions on the healing of diabetic foot ulcers.

\section{Search methods}

For this fourth update we searched The Cochrane Wounds Group Specialised Register (searched 21 April 2011); The Cochrane Central Register of Controlled Trials (CENTRAL) (The Cochrane Library 2011, Issue 2); Ovid MEDLINE (2009 to April Week 2 2011); Ovid MEDLINE (InProcess \& Other Non-Indexed Citations, April 20, 2011); Ovid EMBASE (2009 to 2011 Week 15); and EBSCO CINAHL (2009 to 15 April 2011 ).

\section{Selection criteria}

Randomised controlled trials (RCTs) evaluating any method of debriding diabetic foot ulcers and measuring complete healing or rate of healing. There was no restriction on articles/trials based on language or publication status.

\section{Data collection and analysis}

Data extraction and assessment of study quality were undertaken by one review author and checked by an Editor of the Wounds Group.

\section{Main results}

Six RCTs of debridement were identified: four assessed hydrogels, with an additional study evaluating larval therapy against hydrogel and one evaluated surgical debridement. Pooling the three RCTs which compared hydrogel with gauze or standard care suggested that hydrogels are significantly more effective in healing diabetic foot ulcers (Relative Risk 1.84, 95\% Confidence Interval (CI) 1.3 to 2.61 ). Surgical debridement showed no significant benefit over standard treatment. One small trial, available in abstract form only, suggested that larvae resulted in a greater reduction in wound area compared with hydrogel, but this evidence has not been confirmed by publication of full trial results. Other debridement methods such as enzyme preparations or polysaccharide beads have not been evaluated in diabetic foot ulcers.

\section{Authors' conclusions}

There is evidence to suggest that hydrogel increases the healing rate of diabetic foot ulcers compared with gauze dressings or standard care. There is insufficient evidence (one small trial, abstract only) of the effects of larval therapy on diabetic foot ulcers. More research is needed to evaluate the effects of a range of widely used debridement methods and of debridement per se. 


\section{PLAIN LANGUAGE SUMMARY}

\section{Surgical and non-surgical methods of cleaning and removing dead tissue from sores on the feet of people with diabetes.}

People with diabetes often develop foot ulcers (open sores on the feet that go through the skin), which are a serious complication and can themselves result in serious consequences such as amputation. Cleaning and removing dead tissue and callus from the ulcers is a common procedure also know as "debridement" and can be done in several ways, including surgery and special dressings and gels (such as hydrogels). The review found that hydrogel results in faster healing than gauze or standard care. The evidence for other debriding strategies is unclear. 


\section{B A C K G R O U N D}

Approximately $2 \%$ of the UK population is estimated to have diabetes, of whom approximately 200,000 have Type 1 diabetes and more than a million have Type 2 diabetes (Calman 1998). Foot ulceration is thought to affect $15 \%$ of people with diabetes at some time in their lives (Spencer 2000). The complications of diabetes are not limited to the foot; other complications can affect the eyes (cataracts, retinopathy or neurological disturbances), kidneys (due to sclerotic renal disorder peculiar to diabetes), vascular and neurological complications. In addition diabetes renders people more prone to pulmonary tuberculosis, Candida skin infections and other opportunistic infections (Davies 1989). People with diabetes are between 15 and 70 times more likely to undergo lower limb amputations than people without diabetes (SIGN 1997). Prevalence of amputations due to diabetes (excludes loss of toes or single metatarsals) in Scotland is 1\% of people with diabetes (SIGN 1997); the total UK figure is thought to be similar (Macleod 1991). However there is some uncertainty as to the true incidence and prevalence of diabetic foot ulcers as much of the treatment is delivered within the community and outpatients departments where data collection is patchy and surveillance is limited. The cost of the amputation itself is only a small part of the total care, since most patients who have an amputation have many admissions before and after surgery with the average length of stay over 200 days (SIGN 1997).

The cost to the UK National Health Service of diabetic foot ulcers is thought to be about $£ 13$ million per year (King's Fund 1996). However, such costings do not take into account the personal costs to the patient, e.g. a reduction in ability to work; time taken off work; altered body image; worry and threat of amputation; dressing regimens and hospital visits.

Health professionals with an interest in diabetes met in St Vincent over 10 years ago to review the problem of diabetes complications. Many standards for diabetes care were agreed at this meeting, including a $50 \%$ reduction in lower limb amputations by the year 1995 (SVD 1990).

\section{Aetiology of Diabetic Foot Ulcers}

The breakdown of the diabetic foot has traditionally been considered to be the result of peripheral vascular disease, peripheral neuropathy and infection. More recently, other contributory causes, such as psychosocial factors have been implicated (Boulton 2000).

\section{Vascular Pathology}

Disease of blood vessels is a major cause of complications in diabetes and affects all types of vessel (Faris 1991a). The Framingham study reported that more than $50 \%$ of men and women with diabetes had absent foot pulses (Abbott 1990). Peripheral vascular disease (PVD) tends to occur at a younger age in people with diabetes and is more likely to involve smaller blood vessels further away from the heart. Reports from USA, UK and Finland (Pecoraro 1990; Reiber 1999; Siitonen 1993) have confirmed that PVD is a major contributory factor in the pathogenesis of foot ulceration and subsequent major amputations (Boulton 2000).

\section{Neuropathy}

Impairment of nerve function is an important and frequent complication of diabetes. All types of nerve fibres can be involved including motor, sensory and autonomic nerves and the associated functions affected. Impaired nerve function in the foot is common in people with diabetes although the person themselves may be unaware of its presence. Neuropathy remains one of the major factors leading to the development of foot lesions in people with diabetes (Le Quesne 1991).

\section{Sensory neuropathy}

Damage to the nerves carrying signals from the foot renders the foot insensitive to temperature, vibration, pressure and pain and is referred to as sensory neuropathy. The loss of sensation means that small injuries often go undetected.

\section{Motor neuropathy}

Denervation of muscles has important effects on the function of the foot. The small muscles of the foot, the extensor digitorum brevis, lumbrical and interosseus muscles are commonly affected. Paralysis of these small muscles results in the metatarsophalangeal joints becoming hyper extended and the interphalangeal joints becoming flexed. The joints initially remain mobile but later degenerative changes occur and the joints become fixed (Le Quesne 1991). The consequence of such muscle wastage is a foot shape that increases foot pressures.

\section{Autonomic neuropathy}

Autonomic neuropathy is thought to contribute to the pathogenesis of ulceration, neuropathic oedema and Charcot arthropathy (Le Quesne 1991). Impairment of sweating is suggested to contribute, through dehydration, to the formation of hyperkeratotic plaques and fissures in the skin. If this callus (increased glycation of keratin) is allowed to become too thick, it presses on the soft tissues underneath causing ulceration (Edmonds 2000a). Callus is defined as a build up of keratinised skin, in reaction to persistent pressure (Cutting 1999), and will itself exert pressure.

\section{Pathway to Ulceration}

Despite the presence of predisposing factors such as peripheral vascular disease and peripheral neuropathy, an uninjured foot may not develop serious problems. However physical trauma is a potent cause of trouble e.g. a puncture wound, localised pressure, repeated mechanical trauma, heat or chemical injury (Faris 1991b). Where there is sensory impairment, a small lesion may progress because it is not recognised and the source of injury not removed. Impairment of the blood supply may result in delayed healing. Infection is also an important factor responsible for increasing the amount of damaged tissue (Faris 1991b). It is the infection, which increases the amount of damaged tissue present at the initial site of the damage. An ulcer is the result of a break in the dermal barrier, with subsequent erosion of underlying subcutaneous tissue. In severe cases, the breach may be extended to muscle and bone. Lack of sensation allows the damage to progress to ulceration. The progression to ulceration can be attributed to an impaired arterial supply, neuropathy, musculo-skeletal deformities, or a combination of these factors (Bauer 2000).

\section{Current practice}

Debridement is the removal of devitalised, contaminated or foreign material from within or adjacent to a wound, until surrounding healthy tissue is exposed and it is widely practised in diabetic foot 
care (Dorland's 1998). Debridement is also widely regarded as an effective intervention to speed up ulcer healing. It is widely believed that sharp debridement of an ulcer, including the removal of callus (which may surround or 'roof over' the ulcer) and all devitalised tissue is essential to healing, though direct evidence of this is lacking. Once an ulcer has developed the aim is to heal it in as short a time period as possible and prevent recurrence. Margolis conducted a meta analysis of the control group healing of 10 treatment trials in people with diabetic neuropathic foot ulcers and estimated that $24 \%$ heal within 12 weeks and $31 \%$ by 20 weeks with good wound care (Margolis 1999). High quality management of the diabetic foot is generally regarded as requiring multidisciplinary input and good communication between primary and secondary care providers (Young 2000).

Edmonds (Edmonds 2000b) suggests six aspects of "control" to be addressed when caring for people with diabetes, particularly in relation to foot health:

- mechanical control;

- wound control;

- microbiological control;

- vascular control;

- metabolic control;

- educational.

\section{Debridement}

Debridement (see Table 1 Methods of debridement) is recommended by the SIGN diabetic foot guidelines (SIGN 1997) alongside antibiotic therapy for infection and pressure relief as a treatment for patients who have developed ulceration or gangrene with risk of amputation. The Royal College of General Practitioners' Guidelines (RCGP 2000) also recommend debridement as a treatment of the ulcerated foot alongside local wound management and appropriate dressings. Neither of the guidelines recommend a specific method of debridement.

Edmonds 2000b gave the following rationale for debridement of neuropathic ulcers; it:

- enables the true dimensions of the ulcer to be perceived

- allows drainage of exudate and removal of dead tissue, both render infection less likely

- enables a deep swab to be taken for culture

- encourages healing.

It is the evidence to support this last statement which this review will scrutinise.

\section{O B J E C T IVES}

This review aims to assess the effects of debridement interventions on the healing of diabetic foot ulcers.

\section{METHOD S}

\section{Criteria for considering studies for this review}

\section{Types of studies}

Randomised controlled trials (RCTs), either published or unpublished, which measure the effects on ulcer healing of one or more methods of debridement in the treatment of diabetic foot ulcers.

\section{Types of participants}

People with Type 1 or 2 diabetes, with an active foot ulcer of neuropathic, neuroischaemic or ischaemic aetiology.

\section{Types of interventions}

Comparison of any method of debridement (i.e. the removal of necrotic tissue from the wound, by either mechanical or nonmechanical debridement) with no debridement or an alternative method of debridement.

\section{Types of outcome measures}

\section{Primary outcomes}

1. Time to complete healing.

2. Proportion of people whose ulcers heal completely in the trial period.

3. The rate of reduction in wound size expressed in either absolute or relative terms.

\section{Secondary outcomes}

1. The proportion of ulcers recurring after healing.

2. Number of complications/adverse events reported.

3. Quality of life.

\section{Search methods for identification of studies}

Search methods for the third update of this review are shown in Appendix 1.

\section{Electronic searches}

For this fourth update we searched the following electronic databases to find reports of relevant RCTs:

- The Cochrane Wounds Group Specialised Register (searched 21 April 2011);

- The Cochrane Central Register of Controlled Trials (CENTRAL) (The Cochrane Library 2011, Issue 2);

- Ovid MEDLINE (2009 to April Week 2 2011);

- Ovid MEDLINE (In-Process \& Other Non-Indexed Citations, April 20, 2011);

- Ovid EMBASE (2009 to 2011 Week 15);

- EBSCO CINAHL (2009 to 15 April 2011).

The search strategies for Ovid MEDLINE, Ovid EMBASE and EBSCO CINAHL can be found in Appendix 2, Appendix 3 and Appendix 4 respectively. The Ovid MEDLINE search was combined with the Cochrane Highly Sensitive Search Strategy for identifying randomised trials in MEDLINE: sensitivity- and precisionmaximizing version (2008 revision); Ovid format (Lefebvre 2011). The EMBASE and CINAHL searches were combined with the trial filters developed by the Scottish Intercollegiate Guidelines Network (SIGN) (SIGN 2009). No date or language restrictions were applied.

\section{Searching other resources}

We searched the bibliographies of all retrieved and relevant publications identified further studies. 


\section{Data collection and analysis}

\section{Selection of studies}

For the original review and subsequent updates, one author assessed the titles and abstracts of studies in terms of their relevance and design, according to the selection criteria. Full versions of articles were obtained if they were judged by this initial assessment to potentially satisfy the inclusion criteria. Full papers were checked to identify those meeting the inclusion criteria; any full papers which were rejected were checked by a member of editorial base staff (Sally Bell-Syer, Managing Editor).

\section{Data extraction and management}

If data were missing from reports, then attempts were made to contact the authors to obtain missing information. This was only the case where the studies were only published in abstract form. Data from studies published in duplicate were included only once. Data extraction was undertaken by one author and checked by a member of editorial base staff. Any disagreements were resolved by referring to the editorial base.

The following data were extracted for each review:

- patient inclusion/exclusion criteria;

- care setting;

- key baseline variables by group (e.g. age, sex, baseline risk, baseline area of ulceration);

- description of intervention;

- number of patients randomised to each intervention;

- description of co-interventions/standard care;

- period of follow-up;

- outcomes (time to complete healing; proportion of people whose ulcers healed completely within the trial period; rate of reduction of wound size; proportion of ulcers recurring; number of complications/adverse events; quality of life).

\section{Assessment of risk of bias in included studies}

The methodological strength of each study was appraised using a standard risk of bias checklist for the following criteria:

- sequence generation;

- allocation concealment;

- blinding;

- incomplete outcome data;

- selective reporting of outcomes;

- other bias.

\section{Assessment of heterogeneity}

Clinical heterogeneity was explored by examining trial related factors that may have influenced study outcomes such as concurrent use of antibiotics, pressure relieving devices, frequency of dressing changes, care setting, patient and ulcer characteristics. The chi-squared test was used to test for statistical heterogeneity, whilst $\mathrm{I}^{2}$ was used to estimate the extent of heterogeneity.

\section{RES U LTS}

\section{Description of studies}

Six eligible randomised control trials (RCTs) were identified. Five out of six evaluated the effectiveness of a hydrogel as a method of debridement against a range of comparators.

The first hydrogel trial compared the effectiveness of sodium carboxymethylcellulose (NaCMC) aqueous based-gel (hydrogel) plus good wound care with good wound care alone (D'Hemecourt 1998). In this trial good wound care for all groups consisted of initial and ongoing sharp debridement of ulcers when necessary to remove nonviable tissue, daily saline dressing changes, off loading of pressure and systematic control of infection if present. One trial compared a hydrogel wound dressing (HWD) with wet-to-moist saline gauze (Jensen 1998). The third hydrogel trial compared an "immunomodulating" hydrogel, containing $65 \%$ glycerin (giving it a bacteriostatic action), with dry gauze (Vandeputte 1997). A fourth hydrogel trial compared the effectiveness of hydrogel with larval therapy (Markevich 2000). A fifth hydrogel trial compared the effectiveness of two alternative hydrogels (Whalley 2001) although the extent to which the composition of the different hydrogels differed is unclear from the reports.

The sixth trial compared surgical debridement with conservative, non-surgical debridement (consisting of weight-bearing relief and regular dressings) (Piaggessi 1998).

Only two trials identified neuropathy as the primary aetiology of the included wounds (Markevich 2000; Piaggessi 1998). Four trials did not report on the primary aetiology and classified the wounds merely as "diabetic foot ulcers".

\section{Inclusion / exclusion criteria}

The reporting of inclusion and exclusion criteria was extremely variable amongst the six trials with only. D'Hemecourt 1998 reporting precise inclusion and exclusion criteria. Although Jensen 1998 had clear inclusion criteria, no exclusion criteria were listed: in such cases where criteria were not listed, it was presumed that all people with diabetic foot ulcers were eligible for inclusion in the trial. Markevich 2000 makes no reference to inclusion or exclusion criteria. Three trials (Markevich 2000; Piaggessi 1998; Vandeputte 1997) entered people with diabetic foot ulcers into their trials regardless of ulcer size, depth, duration or blood supply. Vandeputte 1997 had a single exclusion criterion of patients receiving systemic antibiotics. Whalley 2001 has only been reported as a series of conference abstracts with limited data available: authors were contacted for more information which was not forthcoming (see Table 2).

\section{Sample size}

Small sample size was the major deficiency of most of these trials. Two of the trials (D'Hemecourt 1998; Markevich 2000) recruited 140 patients or more. D'Hemecourt 1998 conducted a three arm trial, involving 172 patients and was the largest study included. One trial (Whalley 2001) recruited 74 patients; the other three trials each recruited fewer than 50 patients.

\section{Study Settings}

The study setting was described in two studies (Jensen 1998; Piaggessi 1998) where patients were seen in the outpatients' 
department. Only one trial stated that the source of patients was the diabetic foot clinic (Piaggessi 1998); the five remaining trials did not state where participants were recruited from. The primary outcome of all six trials was complete wound closure, either the time taken to achieve complete wound closure or the proportions of wounds achieving complete wound closure were reported. Three of the trials reported healing rates as an outcome (D'Hemecourt 1998; Jensen 1998; Piaggessi 1998).

\section{Results of the search}

The search for this fourth update retrieved 93 new citations, four of which were considered potentially relevant after initial screening. After further consideration one study was excluded from the review (Abbruzzese 2009) and three studies were added to 'awaiting assessment' as we were attempting to retrieve full text versions or had contacted the study authors for additional information to inform the decision on inclusion (Biliaieva 2009; Cardinal 2009; Singh 2006).

\section{Risk of bias in included studies}

A risk of bias assessment was conducted for each of the included trials (see Characteristics of included studies). Reporting of the conduct of trials was poor across all six included studies, so that it was difficult to evaluate each trial for potential sources of bias. Sequence generation and allocation concealment were not reported for any of the six trials. Blinding of outcome assessors was only reported by D'Hemecourt 1998. Blinding of participants and blinding of personnel delivering the intervention were not apparent in each of the trials as reported. In the absence of adequate methodological reporting, all six trials were deemed to be at high risk of bias (see Figure 1; Figure 2).

Figure 1. Methodological quality graph: review authors' judgements about each methodological quality item presented as percentages across all included studies.

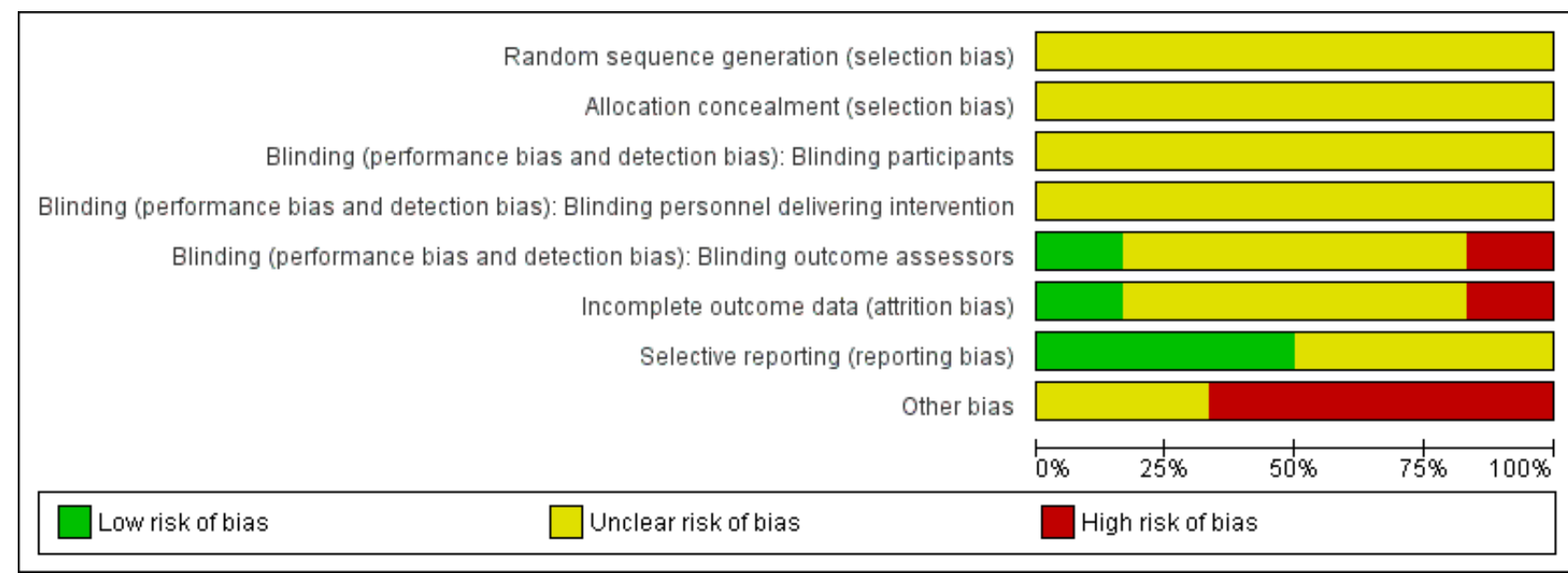


Figure 2. Methodological quality summary: review authors' judgements about each methodological quality item for each included study.

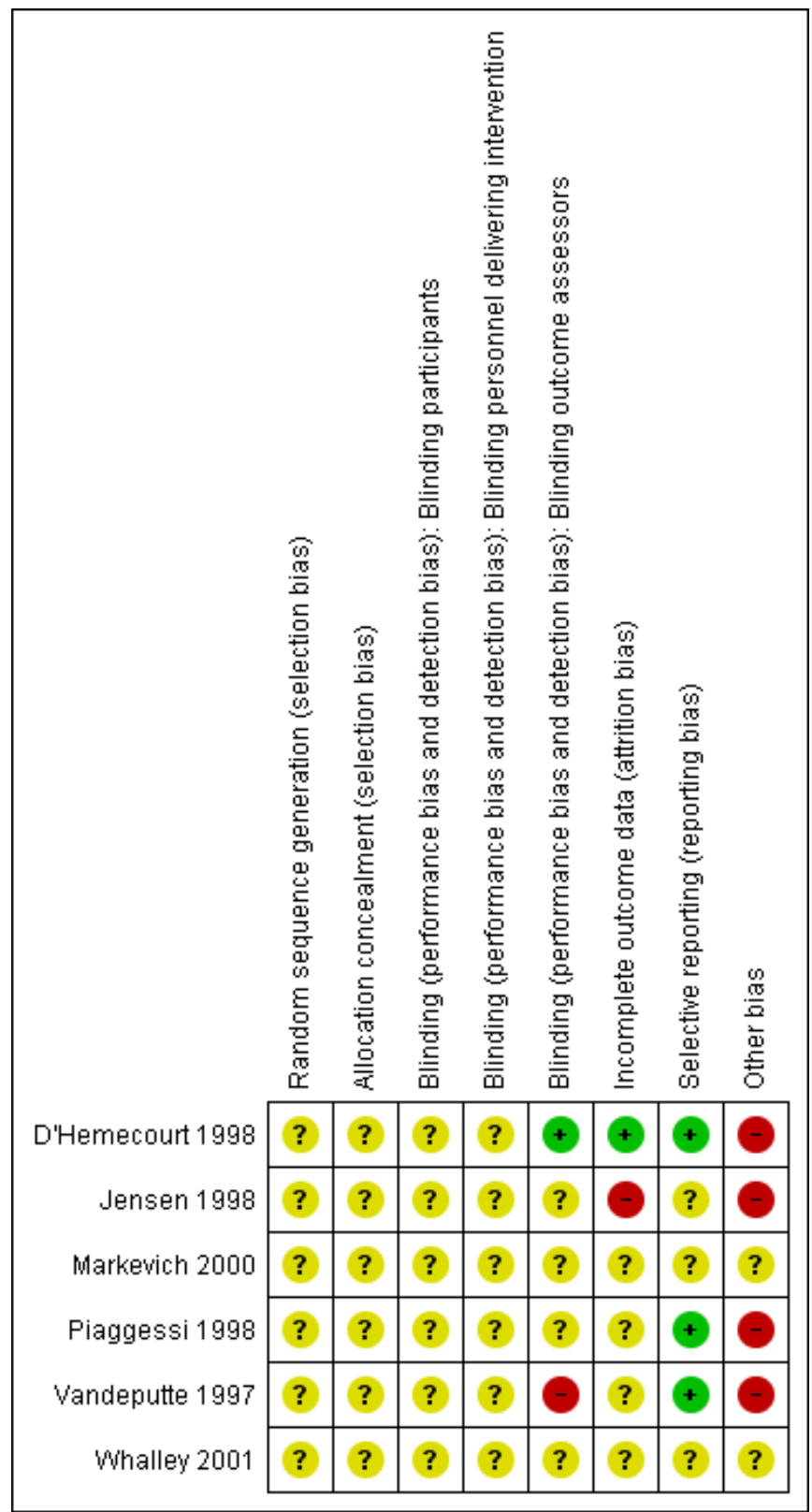

\section{Sequence generation}

(See Characteristics of included studies)

Random allocation to intervention groups remains the only method of ensuring that the only systematic difference between the treatment groups is the intervention itself, thus eliminating selection bias. The success of randomisation depends on two interrelated processes. The first entails generating a sequence by which participants in a trial are allocated to intervention groups. To ensure unpredictability of that allocation sequence, investigators should generate it by a random process (e.g. computer generated numbers, random number tables or coin flipping) (EBN 2001). Sequence generation was not reported for any of the six included trials.

\section{Allocation concealment}

This is the part of the allocation process and shields those involved in the trial from knowing upcoming assignments in advance. Without this protection, investigators have been known to change who gets the next assignment, thus introducing selection bias (EBN 2001). Because of poor reporting, we could not be confident that allocation was concealed in any of the included trials.

\section{Blinding}

Blinding of participants and of personnel delivering the intervention was not clear across all included studies. Of the six RCTs in this review, we could be confident that blinded outcome assessment had been used in only one trial (D'Hemecourt 1998). Markevich 2000 reported that the study was double blinded, 
although they did not report who was blinded (it may be any or all of outcome assessor, patient, clinician or data analyst - see Devereaux 2002). The other three trials (Jensen 1998; Piaggessi 1998; Vandeputte 1997) did not appear to use blinded outcome assessments. Vandeputte 1997 photographed the wounds every four weeks although it was unclear if and how these photographs were used in the analysis. Whalley 2001 reported no information on blinding.

\section{Incomplete outcome data}

Four of the six trials addressed loss to follow up. Two studies reported no withdrawals (Piaggessi 1998; Vandeputte 1997) and two studies accounted for the withdrawals which had taken place (D'Hemecourt 1998; Jensen 1998). This is important because excluding those people who withdrew from a study may lead to a misleading estimate of effectiveness as patients withdraw for non random reasons, including treatment failure.

An intention-to-treat analysis analyses participants in the groups to which they were randomised, irrespective of the treatment received. Three of the six trials (D'Hemecourt 1998; Markevich 2000; Vandeputte 1997) explicitly used an intention-to-treat analysis.

\section{Selective reporting of outcomes}

Three of the included trials pre-specified study outcomes, all of which were reported (D'Hemecourt 1998; Piaggessi 1998; Vandeputte 1997). Jensen 1998 did not clearly pre-specify study outcomes nor did the two conference reports (Markevich 2000; Whalley 2001). Therefore, selective reporting of outcomes was not discernible in these three trials.

\section{Other bias}

It is essential that the trials involving diabetic foot ulcers ensure baseline comparability of the treatment groups for initial area of ulceration (see Table 3). Margolis 1999 has demonstrated that baseline wound area is an important prognostic variable for foot ulcer healing. Trials involving diabetic foot ulcers (as with any other wound healing trials) often express the change in wound area as the percentage change, which takes into account the initial size of the wound, unlike the absolute change in area (Margolis 1999). For two wounds healing at the same linear rate (as measured by diameter reduction), percentage area calculations will show a larger change for a smaller wound than a big wound. The converse is true when the absolute change in area is measured, since for any unit reduction in wound radius a bigger area reduction will occur for a larger wound (Bradley 1999). This has important consequences for the validity of trial results where there is poor comparability of wound size at baseline between the treatment groups. In large trials random allocation should ensure that the average wound size and variance in each group is similar. In a small trial random allocation is unlikely to result in an even distribution of wound sizes. In a trial where there is poor comparability between groups for wound size at baseline, and the outcome is based on the change in area, the result can only be considered valid if it is obtained either: against the anticipated direction of the bias for wound size, or where percentage area change and absolute area change are in the same direction. If baseline data are not given, then it is not possible to determine the direction of bias and the validity of the result cannot be determined.
Of the trials included, one trial (Markevich 2000) demonstrated their treatment groups were balanced for ulcer area at baseline. D'Hemecourt 1998 reported that the ulcers in group treated with Becaplermin gel were different with respect to mean ulcer area, depth and duration of ulcer than were the ulcers in the other two groups ( $\mathrm{NaCMC}$ gel comparator group and 'good wound care' control group); also sharp debridement was employed as deemed appropriate by the study investigator (see Characteristics of included studies). In the trial by Piaggessi 1998 the surgical debridement intervention group only were given antibiotics five days after surgery. In addition, one study (Jensen 1998) was supported by an educational grant from the manufacturer of the hydrogel under assessment.

\section{Effects of interventions}

Results of dichotomous variables are presented as relative risk (RR) with 95\% confidence intervals $(\mathrm{Cl})$. Relative risk has been used rather than odds ratios as the event rates are high in these trials and odds ratios would give an inflated impression of the magnitude of effect (Deeks 1998). Relative risk of healing is the healing rate in the experimental group divided by the healing rate in the control group. The relative risk indicates the relative benefit of a therapy but not the actual benefit, i.e. it does not take into account the number of people whose ulcer would have healed without therapy.

\section{Comparison 1: Surgical debridement compared with conventional non surgical management (1 trial, 42 participants)}

In this trial (Piaggessi 1998) the surgical debridement group underwent surgical excision, eventual debridement or removal of bone segments underlying the lesion and surgical closure. The conventional management group received pressure relief and regular dressings (the type of dressing was not reported).

\section{Primary outcomes}

\section{Proportion of ulcers completely healed within 6 months}

Conservative care healed 19/24 (79\%) ulcers, compared with $21 / 22$ (95\%) of ulcers treated by surgical debridement, RR $1.21(95 \% \mathrm{Cl}$ 0.96 to 1.51$)(P=0.1)$ (no statistically significant difference) (Analysis $1.1)$.

\section{Time to complete healing}

The ulcers treated with conservative methods took longer to heal on average; 129 (+/- 87 days) compared with the surgically treated group whose healing time was 47 (+/- 39 days). It was unclear in the trial whether the figures presented here in parentheses were ranges, standard errors or standard deviations. There was insufficient data provided to determine whether this difference was statistically significant. Baseline data were collected for the type and duration of diabetes, the age of patients and their HBA1c. From the reported data, each group seemed balanced for baseline variables (Analysis 1.2).

\section{Secondary outcomes}

\section{Proportion of ulcers recurring after healing}

In the non-surgical treatment group, $8 / 24(33 \%)$ ulcers recurred within six months, compared with $3 / 22(14 \%)$ in the surgical debridement group; RR $0.41(95 \% \mathrm{Cl} 0.12$ to 1.35$)(\mathrm{P}=0.1)$ (no statistically significant difference) (Analysis 1.3). 


\section{Number of complications/adverse events reported}

In the conservative treatment group $3 / 24$ (13\%) patients became infected compared with $1 / 22(5 \%)$ of patients in the surgical group; RR 0.33 (95\% Cl 0.03 to 3.47) (Analysis 1.4). This difference was not statistically significant $(P=0.3)$. The abstract did not report how infection was diagnosed.

\section{Quality of life}

No data were reported although Piaggessi 1998 claimed that patients reported a higher degree of satisfaction with surgical debridement as well as lower discomfort but did not report how this outcome was measured and whether a valid scale was used.

\section{Comparison 2: Larvae compared with hydrogel (1 trial, 140 participants)}

This study has been published in abstract form only (Markevich 2000) and is of concern, since the abstract reports follow up data at only 10 days whilst the trial was reported to be of 30 months duration. Attempts to contact the authors have been unsuccessful. The outcomes reported in this abstract were: number of wounds completely healed, reduction of more than $50 \%$ in wound area and the proportion of patients with granulation tissue covering over $50 \%$ of the wound. The first two outcomes were pre-specified for this review and are reported here. The trial involved 140 patients, all with diabetic neuropathic foot lesions.

\section{Proportion of ulcers completely healed}

In the larvae group 5/70 (7\%) patients achieved complete healing, compared with 2/70 (3\%) patients from the hydrogel group; RR 2.5 ( $95 \% \mathrm{Cl} 0.5$ to 12.5 ) (no statistically significant difference) (Analysis 2.1). It is unclear from the abstract how long it took to achieve wound healing in either group.

\section{Reduction of more than $50 \%$ in wound area}

In the larvae group 36/70 (51\%) patients showed a wound area reduction of more than $50 \%$ compared with $19 / 70(27 \%)$ patients in the hydrogel group; RR 1.89 (95\% Cl 1.21 to 2.96) (Analysis 2.2). This difference is statistically significant in favour of larvae therapy. However, caution must be expressed as this is very early study data (10 days) and the complete trial results have not been published.

\section{Comparison 3: Hydrogel compared with gauze/standard care (1 trial, 31 participants)}

\section{Trial 1: Hydrogel compared with wet to moist saline gauze}

This trial (Jensen 1998) recruited 31 diabetic patients with foot ulcers of at least $1 \mathrm{~cm}$ diameter with no evidence of infection in the ulcer or peri-wound tissue.

\section{Primary outcomes}

\section{Proportion of ulcers completely healed}

In the hydrogel group 12/14 (86\%) of patients healed completely compared with 6/17(46\%) in the control group, RR 2.43 (95\% Cl 1.23 to 4.79) (a statistically significant difference in favour of hydrogel) (Analysis 3.1). The average duration of ulceration was longer in the hydrogel group (8.9 months) than in the saline control group (3.0 months), and since ulcer duration is prognostic for healing, the bias at baseline is working against the direction of the results, giving us more confidence in them.

\section{Time to complete healing}

Those ulcers treated with the hydrogel were reported as achieving healing in an average of 10 weeks, with the control group healing in an average of 12 weeks (no statistically significant difference).

\section{Rate of reduction in wound size}

At the end of 16 weeks, the wound closure rate was reported however it is unclear whether these figures relate to the mean or median value and therefore we have reported them in the Characteristics of Included studies only.

\section{Secondary outcomes}

Number of complications/adverse events reported

In the hydrogel group 2/14 (14\%) people had complications compared with $4 / 17$ (24\%) in the control group. The following were regarded as complications: a) worsened and required amputation, b) increased eschar formation, c) developed cellulitis, d) worsened with increased eschar formation), RR 0.61 ( $95 \% \mathrm{Cl} 0.13$ to 2.84 ) (no statistically significant difference) (Analysis 3.2).

\section{Cost effectiveness}

Insufficient data prevented us from determining whether there was any statistically significant difference between the apparent difference in cost effectiveness (hydrogel cost $\$ 7 /$ day compared with $\$ 12 /$ day for the control treatment).

\section{Trial 2: Hydrogel (NaCMC aqueous based gel) compared with good wound care alone (1 trial, 172 participants)}

In this trial (D'Hemecourt 1998) the intention-to-treat population consisted of 172 patients. Baseline comparisons were documented for patient demographic characteristics, gender, race, age, height and weight.

\section{Primary outcomes}

\section{Proportion of ulcers completely healed}

Within a 20 week study period 15/68 (22\%) of patients healed with good wound care alone (daily dressing changes; sharp debridement of ulcer; systemic control of any present infection; off-loading of pressure) compared with $25 / 70(36 \%)$ of patients healed with hydrogel, RR 1.62 (95\% Cl 0.94 to 2.80 ) (no statistically significant difference) (Analysis 3.1).

\section{Time to complete healing}

Complete healing was reported as being achieved in an average of 141 days with good wound care alone and in an average of 98 days with hydrogel. No variance data were provided for this outcome, therefore the results are presented in the narrative.

\section{Secondary outcomes}

\section{Number of complications/adverse events reported}

In the good wound care (GWC) alone group $25 / 68$ (37\%) of patients developed an infection (it is unclear how infection was defined in the paper) compared with 19/70 (27\%) of patients in the hydrogel group, RR $0.74(95 \% \mathrm{Cl} 0.45$ to 1.21$)$ (no statistically significant difference) (Analysis 3.2). 


\section{Quality of life/increase in pain}

In the control group 10/68 (15\%) of patients reported an increase in pain compared with $11 / 70(16 \%)$ in the hydrogel group, RR 1.07 (95\% Cl 0.49 to 2.35 ) (no statistically significant difference) (Analysis 3.3). It is not clear in the reporting of the trial how pain was measured.

\section{Trial 3: "Immunomodulating" hydrogel compared with dry gauze (1 trial, 29 participants)}

Only Vandeputte 1997 made this comparison. Patient characteristics collected at baseline were gender, age, number completely mobile, number less than completely mobile, number of neuropathic ulcers and number of patients with infection before the trial. There were only two outcome measures identified.

\section{Primary outcomes}

\section{Proportion of ulcers completely healed}

After three months $14 / 15$ (93\%) of patients completely healed with hydrogel, compared with $7 / 14(50 \%)$ of patients healed in the dry gauze group (statistically significant difference in favour of hydrogel). RR 1.87 (95\% Cl 1.09 to 3.21) (Analysis 3.1).

\section{Secondary outcomes}

\section{Number of complications/adverse events reported}

One person in the hydrogel group (7\%) developed a wound infection (it is unclear in the paper how infection was defined) compared with $7 / 14(50 \%)$ in the dry gauze group, RR $0.13(95 \% \mathrm{Cl}$ 0.02 to 0.95 ) (no statistically significant difference) (Analysis 3.2).

\section{Summary: Hydrogel compared with gauze/good wound care alone}

The three trials (D'Hemecourt 1998; Jensen 1998; Vandeputte 1997) comparing hydrogel with either gauze dressing or good wound care (dressing not specified) were considered sufficiently similar to pool (in the absence of significant heterogeneity $(P=0.65,12=0 \%)$, using a fixed effect model. Pooling the three hydrogel trials yielded a relative risk of healing with hydrogel of 1.84 (95\% Cl 1.3 to 2.61$)$ (Analysis 3.1). This translates to an absolute increase in the risk of healing with hydrogel of $23 \%$, (95\% $\mathrm{Cl} 10 \%$ to $36 \%)$ and a number needed to treat of five $(95 \% \mathrm{Cl} 2$ to 10$)$ : that is for one additional patient to heal their diabetic foot ulcer, five patients must be treated with hydrogel instead of gauze or standard care (treatment time varied from 12 to 20 weeks).

\section{Number of complication/adverse events reported}

All three trials (D'Hemecourt 1998; Jensen 1998; Vandeputte 1997) reported the incidence of complications/adverse events. There was a total of 22 events in the hydrogel groups, compared with 36 events in the comparison groups. It was decided to pool these trials and although there was some evidence of heterogeneity ( 12 $=31 \%$ ) a fixed effect model was applied. There was a RR of an adverse event of 0.60 (95\% $\mathrm{Cl} 0.38$ to 0.95$)$ (Analysis 3.2) showing a statistically significant difference in favour of hydrogel. If a random effects model is applied, this difference was no longer statistically significant (RR $0.56,95 \% \mathrm{Cl} 0.25$ to 1.25 ).

\section{Comparison 4: Alternative hydrogels}

\section{Hydrogel (Purilon gel) compared with hydrogel (Intrasite gel) (1 trial, 74 participants)}

This comparison was made in only one trial with 74 participants (Whalley 2001). The trial involved people with diabetic foot ulcers. Two outcomes were reported, wound healing and mean change of wound area. The study is only reported in abstract form: the authors have been contacted, however no further information has been received to date.

\section{Primary Outcomes}

\section{Proportion of ulcers completely healed}

66 people were evaluated for this outcome and in the first hydrogel group (Purilon) 35\% achieved complete healing compared with $19 \%$ in the second hydrogel group (Intrasite). The numbers of people in each group were not reported in the abstract, therefore no further analysis is possible.

\section{Rate of reduction in wound size}

66 people were evaluable for this outcome and in the first hydrogel group (Purilon) there was a mean change from $2.5 \mathrm{~cm}^{2}$ (SD 3.2) to $0.6 \mathrm{~cm}^{2}$ (SD 1.1) compared with the second hydrogel group (Intrasite) where there was a mean change from $2.4 \mathrm{~cm}^{2}$ (SD 2.9) to $1.0 \mathrm{~cm}^{2}$ (SD 1.8). No further analysis was possible. since the numbers recruited to each group were not reported.

\section{Secondary outcomes}

\section{Number of complications / adverse events reported}

The abstract reported that there were low grade skin reactions in both groups. Maceration was lower in the first hydrogel group (Purilon) than the comparison group (Intrasite), where $11.6 \%$ (Purilon) of patients needed peri-ulcer skin treatment compared with $22.1 \%$ (Intrasite). As the raw data presented was limited, it is not possible to draw any conclusions with respect to the relative effectiveness of these interventions.

\section{DISCUSSION}

Debridement is practised as an intervention because clinicians believe that it promotes wound healing. It is because of this belief that an outcome measure based on wound healing is valid. The common outcome identified by all the trials was complete wound healing. Methods of debridement employed in the six included trials were surgical debridement, hydrogel and larval therapy. However, the confidence with which we can draw firm conclusions from this review is greatly tempered by:

1. the fact that the trials are at high risk of bias;

2. the diversity of the debriding agents being compared;

3. small sample sizes; and

4. lack of replication studies.

Most of the trials undertaken were small and under powered, running a risk of failing to detect clinically significant differences as statistically significant. Other common methodological flaws such as open randomisation, lack of baseline comparability and lack of blinded outcome assessment further reduce the confidence with which we can regard many of the individual study findings. It is possible to minimise bias in outcome assessment by having 
an assessor who is unaware of the treatment allocation, either in person, or by presenting photographic evidence of the ulcer. Future trials should address these deficiencies.

Firstly, debridement by surgical treatment compared with conventional non surgical management was considered by one small study (Piaggessi 1998). Whilst the study authors concluded that surgical treatment of neuropathic foot ulcers in diabetic patients is more effective compared with conventional treatment, this conclusion was not based on a statistically significant effect and the study was low in power due to its small size. Therefore there is no evidence from RCTs that surgical debridement heals diabetic foot ulcers more rapidly than conservative care.

Secondly, the three trials comparing the effects of hydrogels with gauze or standard care were considered. These trials were generally at moderate to high risk of bias although the largest trial in the review (D'Hemecourt 1998) (172 patients) did report using blinded outcome assessment. When these three trials (D'Hemecourt 1998; Jensen 1998; Vandeputte 1997) were pooled, we demonstrated a statistically significant benefit for healing associated with hydrogel however confidence in this finding should be tempered by the risk of bias in the primary studies.

One trial (Whalley 2001) compared two different hydrogels but reported only limited data and therefore the relative effectiveness of the different hydrogels is still unclear.

The comparison of larvae with hydrogel in 140 patients, is reported in abstract form only, and found no difference in complete wound healing between the two groups but did demonstrate a significant difference in the number of wounds that reduced in area of over 50\% (Markevich 2000).

A trial by Steed 1996, which was excluded from the review on the grounds that it was not a randomised comparison of debridement strategies, raises some important issues. The trial makes a connection between debridement and an increased rate of wound healing. The trial was designed to assess the effects of topically applied growth factor with regard to the healing of diabetic foot ulcers. Before randomisation, all patients underwent aggressive, sharp debridement of callous and necrotic tissue. The influence of this debridement was evaluated by correlating healing rates with debridement. Whilst the results showed that, in general, there was a lower rate of healing in centres where less frequent debridement was performed, these results must be viewed with caution, as they constitute a post hoc analysis of a non-randomised comparison and it cannot be concluded that the only difference between the patients who healed was the extent of debridement received (Steed 1996).

In summary, this review has demonstrated that hydrogel appears to result in better healing rates for diabetic foot ulcers than gauze or standard care. However, since hydrogel functions by increasing the moisture of the wound environment, it is not clear whether this effect is mediated through debridement per se. This review also demonstrated that larvae halved the wound area in just over $50 \%$ of the patients, but there is concern that the study data was reported at 10 days only in a trial of 30 months duration. More rigorous research is required to clarify whether debridement aids the healing of diabetic foot ulcers and if so which is the optimum method.

\section{AUTHORS' CONCLUSIONS}

\section{Implications for practice}

The RCTs on debridement of diabetic foot ulcers are in general small and of poor methodological quality. The evidence suggests that hydrogel increases the healing of diabetic foot ulcers compared with gauze or standard wound care. It is not clear whether this effect is due to debridement. The evidence also suggests that larvae achieve a reduction in wound area.

\section{Implications for research}

Well-designed RCTs of sufficient size and with a long enough duration of follow up are needed to assess the effectiveness of debridement of diabetic foot ulcers. Future trials evaluating debridement need to be properly randomised with concealed allocation, adequate sample size, blinding of outcome assessors, unbiased, and objective in their assessment of ulcer healing. The review strongly suggests that more good quality RCTs are needed to determine the clinical effect of debridement on healing.

\section{ACKNOWLEDGEMENTS}

The Cochrane Wounds Group for their continual support and guidance throughout and specifically to Andrea Nelson. Cochrane Wounds Group referees (Andrew Boulton, Sue O'Meara and Donald Cameron) and Editors (Nicky Cullum, David Margolis and Raj Mani) for their comments to improve the review.

For the first update of the review, Wendy Milborrow (Asst RGC) provided comments on the draft update; incorporated copy editor's recommendations into the review and reformatted references, with the agreement of the author. For the second update Sally BellSyer (Managing Editor) provided comments on the draft update and edited the review after feedback from Nicky Cullum (Co Ed), Ruth Foxlee (TSC) undertook the updated search. 
R E F E R E N C E S

\section{References to studies included in this review}

D'Hemecourt 1998 \{published data only\}

D'Hemecourt PA, Smiell JM, Karim MR. Sodium carboxymethyl cellulose aqueous-based gel vs becaplermin gel in patients with nonhealing lower extremity diabetic ulcers. Wounds 1998;10(3):69-75.

\section{Jensen 1998 \{published data only\}}

Jensen JL, Seeley J, Gillin B. Diabetic foot ulcerations: a controlled, randomized comparison of two moist wound healing protocols: Carrasyn Hydrogel wound dressing and wetto-moist saline gauze. Advances in Wound Care 1998;11(7):1-4.

\section{Markevich 2000 \{published data only\}}

Markevich YO, McLeod-Roberts J, Mousley M, Melloy E. Maggot therapy for diabetic neuropathic foot wounds. Diabetologia: Proceedings of the 36th Annual Meeting of the European Association for the Study of Diabetes 2000;43:Suppl 1: A15.

\section{Piaggessi 1998 \{published data only\}}

* Piaggesi A, Schipani E, Campi F, Romanelli M, Baccetti F, Arvia C, et al. Conservative surgical approach versus nonsurgical management for diabetic neuropathic foot ulcers: a randomized trial. Diabetic Medicine 1998;15(5):412-7.

Piaggessi A, Rizzo L, Campi F, Schipani E. Conservative surgical approach versus non-operative treatment for diabetic neuropathic foot ulcers: a randomized trial. Journal of Endocrinological Investigation 1998;21(7):193.

\section{Vandeputte 1997 \{published data only\}}

Vandeputte J, Gryson L. Diabetic foot infection controlled by immuno-modulating hydrogel containing $65 \%$ glycerine. Presentation of a clinical trial. 6th European Conference on Advances in Wound Management, Amsterdam October 1996. 1997:50-3.

\section{Whalley 2001 \{published data only\}}

Capillas R, Whalley A, Boulton AMJ, Dargis V, Harding K, Van Acker K. Performance characteristics and safety of hydrogels using a non-adhesive foam dressing as secondary dressing in the treatment of diabetic foot ulcers. 12th Conference of the European Wound Management Association;2002, 23-25 May; Granada, Spain. 2002:261.

Van Aker K, Dargis V, Boulton AJM. Performance Characteristics and Safety of Purilon Gel versus Intrasite Gel using biatain nonadhesive dressing as secondary dressing in the treatment of diabetic foot ulcers. Tenth Annual Meeting of the European Tissue Repair Society; 2000, 24-27 May; Brussels, Belgium. 2000:A435.

* Whalley A, Boulton AJM, Harding K, Van Acker K, Capillas R. Performance characteristics and safety of purilon gel versus intrasite using biatain non-adhesive dressing as secondary dressing in the treatment of diabetic foot ulcers. 11th European Tissue Repair Society Annual Conference; 2001 5-8 September; Cardiff, Wales. 2001:49.

\section{References to studies excluded from this review}

Abbruzzese 2009 \{published data only\}

Abbruzzese L, Rizzo L, Fanelli G, Tedeschi A, Scatena A, Goretti C, Macchiarini S, Piaggesi A. Effectiveness and safety of a novel gel dressing in the management of neuropathic leg ulcers in diabetic patients: a prospective double-blind randomized trial. International Journal of Lower Extremity Wounds 2009;8(3):134-40.

\section{Apelqvist 1990 \{published data only\}}

Apelqvist J, Larsson J, Stenström A. Topical treatment of necrotic foot ulcers in diabetic patients: a comparative trial of DuoDerm and MeZinc. British Journal of Dermatology 1990;123(6):787-92.

\section{Apelqvist 1994 \{published data only\}}

Apelqvist J, Larsson J, Tennvall GR. A comparative trial between lodosorb and standard treatment of deep diabetic ulcers including an evaluation of cost-effectiveness. 3rd European Conference on Advances in Wound Management; 1993, 19-22 October; Harrogate, UK. 1994:126.

\section{Armstrong 2000 \{published data only\}}

Armstrong DG, Nguyen HC. Improvement in healing with aggressive edema reduction after debridement of foot infection in persons with diabetes. Archives of Surgery 2000;135:1405-9.

\section{Baker 1994 \{published data only\}}

Baker NR, Creevy J. A randomised comparative pilot study to evaluate Allevyn hydrocellular dressings and Sorbsan calcium alginate dressings in the treatment of diabetic foot ulcers. 3rd European Conference on Advances in Wound Management; 1993, 19-22 October; Harrogate, UK. 1994:170.

\section{Callaghan 1993 \{published data only\}}

Callaghan DP . Assessment of the effectiveness of Debrisan in healing ulceration on pressure areas of diabetic patients' feet. 2nd European Conference on Advances in Wound Management; 1992, 20-23 October; Harrogate, UK. 1993:82.

\section{Dolynchuk 2001 \{published data only\}}

Dolynchuk K. The use of collagenase in the debridement of diabetic foot ulcers: a double-blind prospective randomized study. 7th Annual Conference of the Canadian Association of Wound Care 1-3 November 2001 London, Ontario, Canada. 2001:56.

\section{Gottrup 2001 \{published data only\}}

Gottrup F, Hahn TW, Thomsen JK. Cost-effectiveness of hydrogel treatment in diabetic foot ulcers. 12th Conference of the European Wound Management Association 23-25 May 2002 Granada, Spain. 2002:101.

\section{Gough 1997 \{published data only\}}

Gough A, Clapperton M, Rolando N, Foster AV, PhilpottHoward J, Edmonds ME. Randomised placebo-controlled trial of 
granulocyte-colony stimulating factor in diabetic foot infection. Lancet 1997;350:855-9.

\section{Grayson 1994 \{published data only\}}

Grayson ML, Gibbons GW, Habershaw GM, Freeman DV, Pomposelli FB, Rosenblum BI, et al. Use of ampicillin/sulbactam versus imipenem/cilastatin in the treatment of limb-threatening foot infections in diabetic patients. Clinical Infectious Diseases 1994;18:683-93.

\section{Jude 2004 \{published data only\}}

Jude E. Non-Ischemic Diabetic Foot Ulcers: Effects of Aquacel Ag with Hydrofiber versus Alginate Dressing. 2nd World Union of Wound Healing Societies Meeting; 2004 ,8-13 July; Paris. 2004:21.

\section{Jude 2007 \{published data only\}}

Jude E, Apelqvist, Spraul M, Martini J. Randomized controlled study of diabetic foot ulcers dressed with $\mathrm{Hydrofiber}^{\circledR}$ containing ionic silver or calcium alginate dressings. European Wound Management Association Conference; 2005, 15-17 September; Stuttgart, Germany . 2005 ; Vol. V33-4:106.

* Jude EB, Apelqvist J, Spraul M, Martini J, the Silver Dressing Study Group. Prospective randomized controlled study of Hydrofiber ${ }^{\circledR}$ dressing containing ionic silver or calcium alginate dressings in non-ischaemic diabetic foot ulcers. Diabetic Medicine 2007;24:280-288.

\section{Krupski 1991 \{published data only\}} Krupski WC, Reilly LM, Perez S, Moss KM, Crombleholme PA, Rapp JH. A prospective randomized trial of autologous plateletderived wound healing factors for treatment of chronic nonhealing wounds: a preliminary report. Journal of Vascular Surgery 1991;14:526-32.

\section{Li 2006 \{published data only\}}

Li X-Q, Zhu J-Y, Chen D, Zhu B, Tang B, Zhong Z-F, et al. Effect of wound bed preparation on local treatment of diabetic foot ulcer. Chinese Journal of Clinical Rehabilitation 2006;10(24):48-51.

\section{Martinez-de-Jesus 97 \{published data only\}}

Martinez-de-Jesus FR, Morales-Guzman M, Castaneda M, PerezMorales A, Garcia-Alonso J, Mendiola-Segura I. Randomized single-blind trial of topical ketanserin for healing acceleration of diabetic foot ulcers. Archives of Medical Research 1997;28:95-9.

\section{Mulder 1994a \{published data only\}}

Mulder GD, Patt LM, Sanders L, Rosenstock J, Altman MI, Hanley ME, et al. Enhanced healing of ulcers in patients with diabetes by topical treatment with glycyl-L-histidyl-L-lysine copper. Zeitschrift fur Hautkrankheiten 1994;2:259-69.

\section{Mulder 1994b \{published data only\}}

Mulder GD, Jensen JL, Seeley JE, Peak Andrews K. A controlled randomized study of an amorphous hydrogel to expedite closure of diabetic ulcers. 4th European Tissue Repair Society Meeting; 1994, 25-28 August; Oxford, England. 1994:130 (Abstract 90).
Piaggesi 2001 \{published data only\}

Piaggesi A, Baccetti F, Rizzo L, Romanelli M, Navalesi R, Benzi L. Sodium carboxyl-methyl-cellulose dressings in the management of deep ulcerations of diabetic foot. Diabetic Medicine 2001;18:320-4.

\section{Pollak 1997 \{published data only\}}

Pollak RA, Edington H, Jensen JL, Kroeker RO, Gentzkow GD. A human dermal replacement for the treatment of diabetic foot ulcers. Wounds 1997;9:175-83.

\section{Razzak 1997 \{published data only\}}

Razzak FA, Alam MK, Khan S, Al-Bunyan AR, Al-Eshawy S, AlKhelawi A. Local insulin therapy in diabetic foot. JK Practitioner 1997;4:6-8.

\section{Saap 2002 \{published data only\}}

Saap LJ, Falanga V. Debridement performance index and its correlation with complete closure of diabetic foot ulcers.. Wound Repair and Regeneration 2002;10(6):354-9.

Seidel 1994 \{published data only\}

Seidel C, Buhler Singer S, Tacke J, Hornstein OP. Therapeutic superiority of regional retrograde venous antibiotic pressure infusion versus systemic venous infusions in diabetic patients with infected neuropathic plantar ulcers. Hautarzt 1994;45:74-9.

\section{Steed 1996 \{published data only\}}

Steed DL, Donohoe D, Webster M, Lindsley L, PDGF Study Group. Extensive debridement of human diabetic foot ulcers is a vital adjunct to healing. 5th Annual Meeting of the European Tissue Repair Society; 1995, August 30-September 2; Padova, Italy. 1995:371.

* Steed DL, Donohoe D, Webster MW, Lindsley L - Diabetic Ulcer Study Group. Effect of extensive debridement and treatment on the healing of diabetic foot ulcers. Journal of the American College of Surgeons 1996;183:61-4.

\section{Varma 2006 \{published data only\}}

Varma AK, Bal A, Kumar H, Kesav R, Nair S. Efficacy of polyurethane foam dressing in debrided diabetic lower limb wounds. Wounds: A Compendium of Clinical Research and Practice 2006;18(10):300-6.

\section{Wieman 1998 \{published data only\}}

Wieman TJ, Smiell JM, Su Y. Efficacy and safety of a topical gel formulation of recombinant human platelet-derived growth factor-BB (becaplermin) in patients with chronic neuropathic diabetic ulcers. A phase III randomized placebo-controlled double-blind study. Diabetes Care 1998;21:822-7.

\section{References to studies awaiting assessment}

\section{Biliaieva 2009 \{published data only\}}

Biliaieva OO, Neshta VV, Kurylyshyn VP. Effect of new generation application sorbents on the results of complex treatment in patients with diabetic foot syndrome. Klinichna khirurhiia / Ministerstvo okhorony zdorov'ia Ukrainy, Naukove tovarystvo khirurhiv Ukrainy 2009;5:35-7. 


\section{Cardinal 2009 \{published data only\}}

Cardinal M, Eisenbud DE, Armstrong DG, Zelen C, Driver V, Attinger $C$, et al. Serial surgical debridement: a retrospective study on clinical outcomes in chronic lower extremity wounds. Wound Repair and Regeneration 2009;17(3):306-11.

Singh 2006 \{published data only\}

Singh A. Usage of ultrasound in wound management comparison between ultrasonic wound debridement and sharp debridement in diabetic foot ulcers : A randomized clinical trial. University of Malaya 2006.

\section{Additional references}

\section{Abbott 1990}

Abbott RDF, Brand FN, Kannel WB. Epidemilogy of some peripheral arterial findings in diabetic men and women: experiences from the Framingham study. American Journal of Medicine 1990;88:376-81.

\section{Bauer 2000}

Bauer ES. Foot ulcers. Primary Care 2000;343:(11):787-93.

\section{Boulton 2000}

Boulton A. The Pathway to Ulceration: Aetiopathogenesis. In: Boulton A, Connor H, Cavanagh PR editor(s). The Foot in Diabetes. 3rd Edition. Chichester: John Wiley \& Sons Ltd, 2000:19-31.

\section{Bradley 1999}

Bradley M, Cullum N, Sheldon T. The debridement of chronic wounds: A systematic review. Health Technology Assessment 1999; Vol. 3, issue 17:1-2.

\section{Calman 1998}

Calman K. On the state of the public health. The Annual Report of The Chief Medical Officer of The Department Of Health For The Year 1997. The Stationery Office, 1998.

\section{Cutting 1999}

Cutting K. Glossary. In: Miller M, Glover G editor(s). Wound Management Theory and Practice. London: Johnson \& Johnson Medical Ltd, 1999:170-3.

\section{Davies 1989}

Davies M. Metabolic Disorders. In: Neale D, Adams I editor(s). Common Foot Disorders. 3rd Edition. Edinburgh: Churchill Livingstone, 1989:353-61.

\section{Deeks 1998}

Deeks J. Odds ratios should be used only in case control studies and logistic regression analyses. BMJ 1998;317:1155-6.

\section{Devereaux 2002}

Devereaux PJ, Mohit Bhandari MD, Montori VM, Manns BJ, Ghali WA, Guyatt GH. "Double blind, you are the weakest link goodbye!”. Evidence Based Medicine 2002;7:4-5.

\section{Dorland's 1998 [Computer program]}

Dorland. Dorland's Electronic Medical Dictionary (CD-ROM). Version 28th. W.B. Saunders Company, 1998.

\section{EBN 2001}

Notebook. Assessing allocation concealment and blinding in randomised controlled trials: why bother?. Evidence Based Nursing 2001;4:4-6.

\section{Edmonds 2000a}

Edmonds M, Foster A. Stage 2: The high-risk foot. Managing the Diabetic Foot. London: Blackwell Science, 2000:35-44.

\section{Edmonds 2000b}

Edmonds M, Foster A. Stage 3: The ulcerated foot. Managing the Diabetic Foot.. London: Blakewell Science, 2000:45-76.

\section{Faris 1991a}

Faris I. Vascular disease. In: Faris I editor(s). The Management of the Diabetic Foot. 2nd Edition. Edinburgh: Churchill Livingstone, 1991:9-40.

\section{Faris 1991b}

Faris I. Mechanisms for the development of foot lesions. In: Faris I editor(s). The Management of the Diabetic Foot. 2nd Edition. Edinburgh: Churchill Livingstone, 1991:5-9.

\section{King's Fund 1996}

King's Fund. Counting the Cost. The real impact of non-insulin dependent diabetes. London: England: King's Fund Policy Unit, 1996.

\section{Le Quesne 1991}

Le Quesne P, Parkhouse N, Faris I. Neuropathy. In: Faris I editor(s). The Management of the Diabetic Foot. 2nd Edition. Edinburgh: Churchill Livingstone, 1991:41-64.

\section{Lefebvre 2011}

Lefebvre C, Manheimer E, Glanville J, on behalf of the Cochrane Information Retrieval Methods Group. Chapter 6: Searching for studies. In: Higgins JPT, Green S (editors). Cochrane Handbook for Systematic Reviews of Interventions Version 5.1.0 [updated March 2011]. The Cochrane Collaboration, 2011. Available from www.cochrane-handbook.org.

\section{Macleod 1991}

Macleod AF, Williams DR, Sonksen PH, Boulton AJ. Risk factors for foot ulcers in diabetic patients attending a hospital clinic. Diabetologia 1991;34(Suppl):A39.

\section{Margolis 1999}

Margolis D, Kantor J, Berlin J. Healing of Diabetic Neuropathic Foot Ulcers Receiving Standard Treatment. Diabetes Care 1999;22:692-5.

\section{Pecoraro 1990}

Pecoraro RE, Reiber GE, Burgess EM. Pathways to diabetic limb amputation: basis for prevention. Diabet Care 1990;13:513-21. 


\section{RCGP 2000}

Royal College of General Practioners, British Diabetic Association, Royal College of Physicians, Royal College of Nursing (collaborative programme). Prevention and Management of Foot Problems. Clinical Guidelines for Type 2 Diabetes.. London, March 2000.

\section{Reiber 1999}

Reiber GE, Vileikyte L, Boyko EJ, del Aguila M, Smith DG, Lavery L. Casual Pathways for incident lower extremity ulcers in patients with diabetes from two settings. Diabetes Care 1999;22:157-62.

\section{SIGN 1997}

Scottish Intercollegiate Guidelines Network. Management of diabetic Foot Disease. Implementation of the St. Vincent Declaration. The Care of Patients in Scotland 1997.

\section{SIGN 2009}

Scottish Intercollegiate Guidelines Network (SIGN). Search filters. http://www.sign.ac.uk/methodology/ filters.html\#random (accessed 22 June 2009).

\section{CHARACTERISTICS OF STUDIES}

Characteristics of included studies [ordered by study ID]

\section{Siitonen 1993}

Siitonen OI, Niskanen LK, Laakso M, Siitonen JF, Pyorala K. Lower extremity amputation in diabetic and non-diabetic patients: a population-based study in Eastern Finland. Diabetes Care 1993;16:16-20.

\section{Spencer 2000}

Spencer S. Pressure relieving interventions for preventing and treating diabetic foot ulcers. Cochrane Database of Systematic Reviews 2000, Issue 4. [DOI: 10.1002/14651858.CD002302]

\section{SVD 1990}

The St Vincent Declaration. Diabetes Care and Research in Europe. Diabetic Medicine 1990;7:360.

\section{Young 2000}

Young M.J. Classification of Ulcers and Its Relevance to Management. In: Boulton A. Connor H, Cavanagh P editor(s). The Foot in Diabetes. third. Chichester: John Wiley \& Sons Ltd, 2000:61-72.

* Indicates the major publication for the study

D'Hemecourt 1998

\begin{tabular}{ll} 
Methods & RCT Multi-centred (10 sites); Evaluator-blind; lower extremity diabetic ulcers \\
\hline Participants & 172 patients \\
A) 68 \\
B) 70 \\
C) 34 \\
45 women/127 men; 19 years or older; Type $1 /$ Type 2 diabetes. \\
Wound size (area and depth) measured at baseline.
\end{tabular}

Interventions

\author{
A) Good wound care* \\ B) Good wound care \& NaCMC hydrogel \\ C) Good wound care \& becaplermin \\ Off loading of pressure and systemic control of infection for all wounds.
}

*'Good wound care' was defined by the study authors as follows: "this regimen consisted of daily dressing changes, sharp debridement of the ulcer when deemed necessary by the investigator, systemic control of infection if present, and off-loading of pressure".

Outcomes
A) $15 / 68(22 \%)$
B) $25 / 70(36 \%)$
2. Time to complete healing
A) 141 days *
B) 98 days *
3. Wound related adverse events
A) $25 / 68(37 \%)$
B) $19 / 70(27 \%)$
4. Quality of life (pain reported as adverse event)
A) $10 / 68(15 \%)$
B) $11 / 70(16 \%)$


D'Hemecourt 1998 (Continued)
Notes
Largest trial with regard to patient numbers
${ }^{\star}$ It is unclear if these are mean or median times to healing.

\title{
Risk of bias
}

Bias Authors' judgement Support for judgement

\begin{tabular}{|c|c|c|}
\hline $\begin{array}{l}\text { Random sequence genera- } \\
\text { tion (selection bias) }\end{array}$ & Unclear risk & $\begin{array}{l}\text { Exact sequence generation procedure was not reported: "patients were ran- } \\
\text { domly assigned in a 2:2:1 ratio to one of three treatment groups". }\end{array}$ \\
\hline
\end{tabular}

$\begin{array}{ll}\text { Allocation concealment } & \text { Unclear risk }\end{array}$

(selection bias)

Blinding (performance Unclear risk

bias and detection bias)

Blinding participants

\begin{abstract}
Statement by authors from published study: "both the NaCMC gel and becaplermin gel treatment groups were conducted in double-blind fashion; the group receiving good wound care alone was blinded to the investigator by a third party".

Blinding of participants: unclear (see statement from authors above).
\end{abstract}

\begin{tabular}{|c|c|c|}
\hline $\begin{array}{l}\text { Blinding (performance } \\
\text { bias and detection bias) }\end{array}$ & Unclear risk & $\begin{array}{l}\text { Blinding of personnel delivering the intervention: yes - control group; unclear - } \\
\text { intervention groups (see statement from authors above). }\end{array}$ \\
\hline
\end{tabular}

Blinding personnel deliv-

ering intervention

Blinding (performance Low risk

Blinding of outcomes assessor: yes. Study described as "evaluator-blind".

bias and detection bias)

Blinding outcome asses-

sors

\begin{tabular}{|c|c|c|}
\hline $\begin{array}{l}\text { Incomplete outcome data } \\
\text { (attrition bias) } \\
\text { All outcomes }\end{array}$ & Low risk & Intention-to-treat analysis was conducted. \\
\hline $\begin{array}{l}\text { Selective reporting (re- } \\
\text { porting bias) }\end{array}$ & Low risk & Four parameters pre-specified as outcomes, all of which were reported. \\
\hline Other bias & High risk & $\begin{array}{l}\text { Baseline differences in group size and ulcer characteristics (mean area, depth } \\
\text { and duration): } \\
\text { Good wound care }(\mathrm{n}=68): \mathrm{n}=65 \text { at stage III; } 3.5 \mathrm{~cm}^{2} ; 67 \mathrm{~cm} ; 24 \text { weeks. } \\
\text { NaCMC gel }(\mathrm{n}=70): \mathrm{n}=70 \text { at stage III; } 3.2 \mathrm{~cm}^{2} ; 69 \mathrm{~cm} ; 24 \text { weeks. } \\
\text { Becaplermin gel }(\mathrm{n}=34): \mathrm{n}=32 \text { at stage III; } 2.4 \mathrm{~cm} 2 ; 33 \mathrm{~cm} ; 11 \text { weeks. } \\
\text { The group receiving Becaplermin gel were not comparable with the two other } \\
\text { groups. }\end{array}$ \\
\hline & & $\begin{array}{l}\text { 'Good wound care' in addition included "sharp debridement of the ulcer when } \\
\text { deemed necessary by the investigator". }\end{array}$ \\
\hline
\end{tabular}

\section{Jensen 1998}

\begin{tabular}{ll}
\hline Methods & RCT; Randomised into 2 groups. \\
\hline Participants & 31 patients \\
A) 14 \\
B) 17 \\
No description of age, sex or type of diabetes.
\end{tabular}


Jensen 1998 (Continued)

Wound area measured at baseline.

Average duration of ulceration

A) 8.9 months

B) 3 months

Anterventions Carrasyn hydrogel wound dressing (CHWD)
B) Wet-to-moist saline gauze
All patients received custom made healing sandals for pressure redistribution

Outcomes
A) $12 / 14(86 \%)$
B) $6 / 17(35 \%)$
2. Healing time
A) 10.3 weeks *
B) 11.69 weeks *
3. Healing rate (reduction in wound area)
A) $84.6 \%$ *
B) $46.1 \%{ }^{*} \mathrm{P}=0.05$
5. Complications
A) $2 / 14(14 \%)$
B) $4 / 17(24 \%)$
7. Cost
A) $7.01-(\$ /$ day $)$
B) $12.28-(\$ /$ day)

Notes * $\quad$ It is unclear if these are mean or median times to healing.

\section{Risk of bias}

\begin{tabular}{|c|c|c|}
\hline Bias & Authors' judgement & Support for judgement \\
\hline $\begin{array}{l}\text { Random sequence genera- } \\
\text { tion (selection bias) }\end{array}$ & Unclear risk & Sequence generation not reported. \\
\hline $\begin{array}{l}\text { Allocation concealment } \\
\text { (selection bias) }\end{array}$ & Unclear risk & Not reported. \\
\hline $\begin{array}{l}\text { Blinding (performance } \\
\text { bias and detection bias) } \\
\text { Blinding participants }\end{array}$ & Unclear risk & Not reported. \\
\hline $\begin{array}{l}\text { Blinding (performance } \\
\text { bias and detection bias) } \\
\text { Blinding personnel deliv- } \\
\text { ering intervention }\end{array}$ & Unclear risk & Not reported. \\
\hline $\begin{array}{l}\text { Blinding (performance } \\
\text { bias and detection bias) } \\
\text { Blinding outcome asses- } \\
\text { sors }\end{array}$ & Unclear risk & Not reported. \\
\hline $\begin{array}{l}\text { Incomplete outcome data } \\
\text { (attrition bias) } \\
\text { All outcomes }\end{array}$ & High risk & $\begin{array}{l}5 \text { patients dropped out ( } n=1 \text { in Group } A ; n=4 \text { in Group B): no intention-to-treat } \\
\text { analysis was conducted. }\end{array}$ \\
\hline $\begin{array}{l}\text { Selective reporting (re- } \\
\text { porting bias) }\end{array}$ & Unclear risk & No parameters clearly pre-specified as outcomes. \\
\hline
\end{tabular}


Jensen 1998 (Continued)

Other bias

High risk
No Group A and Group B data reported on ulcer size and thickness on entry to trial (inclusion criteria - ulcer with minimum of $1 \mathrm{~cm}$ diameter; Wagner grade II thickness). However the trial report suggests that Group A had average ulcer duration of 8.9 months compared with 3 months for group B.

Study supported by an educational grant from Carrington Laboratories, Inc (the manufacturers of Carrasyn).

\section{Markevich 2000}

\begin{tabular}{ll}
\hline Methods & RCT; Multi-centred; Double-blind \\
\hline Participants & 140 patients, \\
A) 70 \\
B) 70 \\
Average age $53.6+/-15.4$ years. \\
No description of sex or type of diabetes. \\
Wound depth measured at baseline. \\
\hline
\end{tabular}

$\begin{array}{ll}\text { Interventions } & \text { A) Larval therapy for } 72 \text { hours } \\ & \text { B) Hydrogel (no data on frequency of dressing change) }\end{array}$

\begin{tabular}{ll}
\hline Outcomes & Complete healing (no data as to time this \\
A) $5 / 70(7 \%)$ \\
B) $2 / 70(3 \%)$ \\
(no statistically significant difference)
\end{tabular}

Notes

\section{Risk of bias}

\begin{tabular}{lll}
\hline Bias & Authors' judgement & Support for judgement \\
\hline $\begin{array}{l}\text { Random sequence genera- } \\
\text { tion (selection bias) }\end{array}$ & Unclear risk & Published abstract only - sequence generation not reported. \\
\hline $\begin{array}{l}\text { Allocation concealment } \\
\text { (selection bias) }\end{array}$ & Unclear risk & Published abstract only - allocation concealment not reported. \\
\hline $\begin{array}{l}\text { Blinding (performance } \\
\text { bias and detection bias) } \\
\text { Blinding participants }\end{array}$ & Unclear risk & $\begin{array}{l}\text { N.B. RCT described as "double-blind" by study authors but no further detail } \\
\text { given. } \\
\text { Blinding of participants - not reported (published abstract only): difficult due } \\
\text { to nature of treatments - larval therapy vs. hydrogel. }\end{array}$ \\
\hline $\begin{array}{l}\text { Blinding (performance } \\
\text { bias and detection bias) } \\
\begin{array}{l}\text { Blinding personnel deliv- } \\
\text { ering intervention }\end{array}\end{array}$ & Unclear risk & $\begin{array}{l}\text { Blinding of personnel - not reported (published abstract only): difficult due to } \\
\text { nature of treatments - larval therapy vs. hydrogel. }\end{array}$ \\
\hline $\begin{array}{l}\text { Blinding (performance } \\
\text { bias and detection bias) } \\
\begin{array}{l}\text { Blinding outcome asses- } \\
\text { sors }\end{array}\end{array}$ & Unclear risk & Blinding of outcome assessors: not reported (published abstract only). \\
\hline
\end{tabular}

$\begin{array}{lll}\text { Incomplete outcome data } & \text { Unclear risk } & \begin{array}{l}\text { Published abstract only - incomplete outcome data assessment not dis- } \\ \text { (attrition bias) }\end{array} \\ \text { cernible. }\end{array}$

All outcomes

cernible. 
Markevich 2000 (Continued)

Selective reporting (re- Unclear risk $\quad$ Published abstract only - selective reporting not discernible. porting bias)

Other bias Unclear risk Published abstract only - other bias not discernible.

\section{Piaggessi 1998}

\begin{tabular}{|c|c|}
\hline Methods & Randomised into 2 groups \\
\hline Participants & $\begin{array}{l}42 \text { patients with } 46 \text { ulcers } \\
\text { A) } 20 \text { patients, } 24 \text { ulcers } \\
\text { B) } 21 \text { patients, } 22 \text { ulcers } \\
\text { No description of age, sex or type of diabetes. } \\
\text { Baseline wound area measurement not reported. }\end{array}$ \\
\hline Interventions & $\begin{array}{l}\text { A) Control - Non-surgical conservative treatment and pressure relief } \\
\text { B) Treatment - Surgical debridement }\end{array}$ \\
\hline Outcomes & $\begin{array}{l}\text { 1. Complete healing at } 6 \text { months: Group } A=\text { complete re-epithelization of lesions; Group } B=\text { formation } \\
\text { of continuous scar } \\
\text { A) } 19 / 24(79 \%) \\
\text { B) } 21 / 22(95 \%) \\
\text { 2. Healing time } \\
\text { A) } 128.9 \text { days * } \\
\text { B) } 46.7 \text { days * } \\
\text { 4. Reoccurrence rate } \\
\text { A) } 8 / 24(33 \%) \\
\text { B) } 3 / 22(14 \%) \\
\text { 5. Infective complications } \\
\text { A) } 3 / 24(13 \%) \\
\text { B) } 1 / 22(5 \%)\end{array}$ \\
\hline
\end{tabular}

Notes * $\quad$ * It is unclear if these are mean or median times to healing.

\section{Risk of bias}

\section{Bias \\ Authors' judgement Support for judgement}

Random sequence genera- Unclear risk Exact sequence generation not reported: "a table of randomisation". tion (selection bias)

\begin{tabular}{lll}
\hline $\begin{array}{l}\text { Allocation concealment } \\
\text { (selection bias) }\end{array}$ & Unclear risk & Not reported. \\
\hline $\begin{array}{l}\text { Blinding (performance } \\
\text { bias and detection bias) } \\
\text { Blinding participants }\end{array}$ & Unclear risk & Non-surgical debridement and pressure relief vs. surgical debridement. \\
& $\begin{array}{l}\text { Blinding of participants: difficult due to nature of treatments - non-surgical } \\
\text { control vs. surgical intervention. }\end{array}$ \\
\hline
\end{tabular}

\begin{tabular}{|c|c|c|}
\hline $\begin{array}{l}\text { Blinding (performance } \\
\text { bias and detection bias) }\end{array}$ & Unclear risk & $\begin{array}{l}\text { Blinding of personnel: difficult due to nature of treatments - non-surgical con- } \\
\text { trol vs. surgical intervention. }\end{array}$ \\
\hline $\begin{array}{l}\text { Blinding personnel deliv- } \\
\text { ering intervention }\end{array}$ & & $\begin{array}{l}\text { Yes - Group A. Physicans and nurses treating Group A (control) patients were } \\
\text { unaware of their patients' involvement in the trial: "the whole treatment } \\
\text { course of group A patients from initial debridement to follow-up visit was per- } \\
\text { formed by physicians and nurses unaware of the participation of patients in }\end{array}$ \\
\hline
\end{tabular}


the study, and did not differ from the standard protocol of treatment of noncomplicated neuropathic ulcerations in our foot clinic".

Unclear - Group B. It was not reported if personnel for the Group B (intervention) were aware of their patients' participation in the trial.

\begin{tabular}{lll}
\hline $\begin{array}{l}\text { Blinding (performance } \\
\text { bias and detection bias) } \\
\begin{array}{l}\text { Blinding outcome asses- } \\
\text { sors }\end{array}\end{array}$ & Unclear risk & $\begin{array}{l}\text { Blinding of outcome assessors: unclear who conducted outcome assessment } \\
\text { for both Groups (A and B). }\end{array}$ \\
\hline $\begin{array}{l}\text { Incomplete outcome data } \\
\text { (attrition bias) } \\
\text { All outcomes }\end{array}$ & Unclear risk & Patient numbers at follow-up were not reported. \\
\hline $\begin{array}{l}\text { Selective reporting (re- } \\
\text { porting bias) }\end{array}$ & Low risk & Four parameters were pre-specified as outcomes, all of which were reported. \\
\hline $\begin{array}{l}\text { Other bias } \\
\text { High risk }\end{array}$ & $\begin{array}{l}\text { Group B given antibiotics } 5 \text { days after surgery: "general therapy for group B } \\
\text { patients differed from group A in that systemic parenteral therapy with wide- } \\
\text { spectrum antibiotics was given } 5 \text { days after surgery, according to the protocols } \\
\text { of our hospital for the prophylaxis of nosocomial infection". }\end{array}$ \\
\hline
\end{tabular}

Vandeputte 1997

\begin{tabular}{ll}
\hline Methods & Pre-prepared randomisation listing \\
\hline Participants & 29 patients with 30 wounds \\
& A) 15 patients (15 wounds) \\
B) 14 patients (15 wounds) \\
No description of age, sex or type of diabetes. \\
Baseline wound area measurement not reported. \\
\hline Interventions & A) Hydrogel \\
& B) Dry gauze (control) \\
\hline Outcomes & Complete Healing at 3 months \\
A) $14 / 15(93 \%)$ \\
B) $7 / 14(50 \%)$ \\
Infective complications \\
A) $1 / 15(7 \%)$ \\
B) $7 / 14(50 \%)$
\end{tabular}

Notes

\section{Risk of bias}

\begin{tabular}{lll}
\hline Bias & Authors' judgement & Support for judgement \\
\hline $\begin{array}{l}\text { Random sequence genera- } \\
\text { tion (selection bias) }\end{array}$ & Unclear risk & $\begin{array}{l}\text { Exact sequence generation procedure was not reported: "patients were allo- } \\
\text { cated to treatment groups according to a pre-prepared randomisation listing". }\end{array}$ \\
\hline $\begin{array}{l}\text { Allocation concealment } \\
\text { (selection bias) }\end{array}$ & Unclear risk & Not reported. \\
\hline $\begin{array}{l}\text { Blinding (performance } \\
\text { bias and detection bias) }\end{array}$ & Unclear risk & Blinding of participants: unclear. \\
\hline
\end{tabular}


Vandeputte 1997 (Continued)

Blinding participants

Blinding (performance Unclear risk Blinding of personnel: unclear.

bias and detection bias)

Blinding personnel deliv-

ering intervention

Blinding (performance

High risk

Blinding of outcome assessors: no - same nurses as personnel and outcome

bias and detection bias) assessors.

Blinding outcome asses-

sors

Incomplete outcome data Unclear risk (attrition bias)

All outcomes
Lack of clarity concerning patient deaths in control group.

Methods and Results sections report control group as $n=14$. Results section states: "one patient of the control group died. One patient had a wound on both legs. Therefore the number of legs treated was 30 (15 in each group)".

Two deaths in the control group are reported in the 'Overall healing time' Table 3 in the Results section: ' 2 - died during trial' in the control group, although the total remains stated as $n=14$.

\begin{tabular}{lll}
\hline $\begin{array}{l}\text { Selective reporting (re- } \\
\text { porting bias) }\end{array}$ & Low risk & Nine parameters were pre-specified as outcomes, all of which were reported. \\
\hline Other bias & High risk & Lead author (Vandeputte) had an affiliation with Elasto-gel's manufacturer. \\
\hline
\end{tabular}

Whalley 2001

\begin{tabular}{|c|c|}
\hline Methods & RCT Randomised into 2 groups \\
\hline Participants & 74 patients; (66 patients evaluated) no further data available. \\
\hline Interventions & $\begin{array}{l}\text { A) Purilon gel } \\
\text { B) Intrasite gel } \\
\text { Dressings changed every second day }\end{array}$ \\
\hline Outcomes & $\begin{array}{l}\text { 1. Complete healing at } 10 \text { weeks } \\
\text { A) } 35 \% \text { healed } \\
\text { B) } 19 \% \text { healed } \\
\text { 2. Change in mean wound area } \\
\text { A) } 2.5 \mathrm{~cm}^{2} \text { (SD 3.2) to } 0.6 \mathrm{~cm}^{2} \text { (SD } 1.1 \text { ) } \\
\left.\text { B) } 2.4 \mathrm{~cm}^{2} \text { (SD 2.9) to } 1.0 \mathrm{~cm}^{2} \text { (SD } 1.8\right) \\
\text { 3. Peri-ulcer maceration } \\
\text { Lower in A than B ( } 11.6 \% \text { vs. } 22.1 \%)\end{array}$ \\
\hline Notes & Abstract only; limited data \\
\hline \multicolumn{2}{|l|}{ Risk of bias } \\
\hline Bias & Authors' judgement Support for judgement \\
\hline $\begin{array}{l}\text { Random sequence genera- } \\
\text { tion (selection bias) }\end{array}$ & Published abstract only - sequence generation not reported. \\
\hline
\end{tabular}


Whalley 2001 (Continued)

$\begin{aligned} & \text { Allocation concealment } \\ & \text { (selection bias) }\end{aligned} \quad$ Unclear risk Published abstract only - allocation concealment not reported.

Blinding (performance

Unclear risk

Published abstract only - blinding not reported.

bias and detection bias)

Blinding participants

Blinding (performance Unclear risk Published abstract only - blinding not reported.

bias and detection bias)

Blinding personnel deliv-

ering intervention

Blinding (performance Unclear risk Published abstract only - blinding not reported.
bias and detection bias)
Blinding outcome asses-
sors

\begin{tabular}{lll}
\hline $\begin{array}{l}\text { Incomplete outcome data } \\
\text { (attrition bias) } \\
\text { All outcomes }\end{array}$ & Unclear risk & $\begin{array}{l}\text { Published abstract only - incomplete outcome data assessment not dis- } \\
\text { cernible. "66 patients were evaluable" from the } 74 \text { patients recruited. }\end{array}$ \\
\hline $\begin{array}{l}\text { Selective reporting (re- } \\
\text { porting bias) }\end{array}$ & Unclear risk & Published abstract only - selective reporting not discernible. \\
\hline Other bias & Unclear risk & Published abstract only - other bias not discernible. \\
\hline
\end{tabular}

Characteristics of excluded studies [ordered by study ID]

\begin{tabular}{|c|c|}
\hline Study & Reason for exclusion \\
\hline Abbruzzese 2009 & Both groups received debridement. \\
\hline Apelqvist 1990 & $\begin{array}{l}\text { RCT did not report on any of the pre-specified outcomes of the review but reported data only on } \\
\text { change in area of necrosis rather than change in area of ulcer/wound. }\end{array}$ \\
\hline Apelqvist 1994 & $\begin{array}{l}\text { Varidase is used as a debriding agent but no separate data was available for this group of patients. } \\
\text { If such data had been available, the size of the study }(n=17) \text { is unlikely to be sufficiently powered. }\end{array}$ \\
\hline Armstrong 2000 & $\begin{array}{l}\text { Although all wounds were debrided the primary intervention measured was a foot compression } \\
\text { system, there was no comparison or conclusions drawn regarding the debridement methods used. }\end{array}$ \\
\hline Baker 1994 & Excluded patients with sloughy/ necrotic wounds. \\
\hline Callaghan 1993 & Insufficient information available. Author contacted but no reply. \\
\hline Dolynchuk 2001 & $\begin{array}{l}\text { Interim study results are in abstract form only. Comparison of Collagenase plus bacitracin with } \\
\text { bacitracin alone. No data reported; author contacted but no reply }\end{array}$ \\
\hline Gottrup 2001 & This is a cost evaluation paper. \\
\hline Gough 1997 & $\begin{array}{l}\text { RCT which compares granulocyte stimulating factor, with a placebo. There is no debriding agent } \\
\text { included in the trial. }\end{array}$ \\
\hline
\end{tabular}




\begin{tabular}{ll}
\hline Study & Reason for exclusion \\
\hline Grayson 1994 & $\begin{array}{l}\text { RCT assessing the effectiveness of imipenem / cilastatin against ampicillin / sulbactam in the treat- } \\
\text { ment of pedal infections in diabetic. No debriding agent was considered. }\end{array}$
\end{tabular}

Jude 2004

RCT of 120 people which compares a silver based fibre dressing with an alginate, neither of which have debriding properties.

\begin{tabular}{ll}
\hline Jude 2007 & Dressing for diabetic foot ulcers was not a debriding agent. \\
\hline Krupski 1991 & $\begin{array}{l}\text { RCT which compared platelet derived wound healing with a placebo. Although all wounds were ex- } \\
\text { tensively debrided initially, there were no debriding agents included in the trial. The trial sample } \\
\text { was 'mixed ulcers' - with leg ulcers mainly identified. }\end{array}$ \\
\hline Li 2006 & Growth factors as focus of RCT. (Debridement to aid growth factor only). \\
\hline Martinez-de-Jesus 97 & $\begin{array}{l}\text { RCT where all foot ulcers under went surgical debridement and were then treated with either top- } \\
\text { ical ketanserin or normal saline (placebo). Excluded as the topical treatment, although gel based } \\
\text { was compounded by the fact that it contained ketanserin gel. }\end{array}$ \\
\hline
\end{tabular}

MCT comparing lamin gel with standard care and vehicle gel. The lamin gel contains a peptide cop-
per complex, which has been shown to be a chemoattractant for capillary endothelial cells and is
angiogenic. It is therefore not a debriding agent

\begin{tabular}{ll}
\hline Mulder 1994b & Report available as abstract only. Letters to authors have failed to elicit further information. \\
\hline Piaggesi 2001 & $\begin{array}{l}\text { RCT with diabetic patients. The type of dressing used in the intervention, however, is not a debride- } \\
\text { ment agent; the use of hydro-fibres allows the dressing to absorb exudate and is concerned with } \\
\text { maintaining a moist environment at the wound surface. }\end{array}$ \\
\hline
\end{tabular}

Pollak 1997 RCT which assesses the effectiveness of human dermis replacement against conventional treat-
ment. There is initially sharp debridement, but there is no debriding agent assessed in the trial.

Razzak 1997 RCT including 24 patients, dividing patients into treatment with either antibiotics or local insulin application. No debriding agent was assessed in this trial.

Salfils the inclusion criteria for RCT and diabetic foot ulcers. The paper, however, is concerned with
measuring the standard of debridement and the effectiveness of a debridement scale rather than
the effectiveness of debridement as a treatment.
Seidel 1994 RCT which assess the use of short term retrograde transvenous leg perfusion. The trial is concerned with infection of foot ulcers; wound healing was not an outcome.

Steed 1996 RCT of 118 patients which compares treatment of human-derived growth factor against a placebo. The influence of debridement was evaluated by reviewing the records of the trial. This paper was used in the discussion section of this review.

\begin{tabular}{ll}
\hline Varma 2006 & $\begin{array}{l}\text { RCT undertaken on people whose wounds had already been debrided, and the effectiveness of the } \\
\text { post debridement dressing was the focus of the trial. }\end{array}$ \\
\hline Wieman 1998 & $\begin{array}{l}\text { RCT of } 382 \text { patients which assessed the efficacy and safety of topically applied recombinant human } \\
\text { platelet derived growth factor at two strengths, either becaplermin } 30 \text { mg or becaplermin } 100 \text { mg. }\end{array}$
\end{tabular}

Characteristics of studies awaiting assessment [ordered by study ID] 
Biliaieva 2009

Methods

\section{Participants}

Interventions

\section{Outcomes}

Notes Ukranian paper, attempting to retrieve full text of the article.

Cardinal 2009

\section{Methods}

\section{Participants}

Interventions

Outcomes

Notes Additional information required from study authors.

Singh 2006

Methods

Participants

Interventions

Outcomes

\section{DATA AND ANALYSES}

\section{Comparison 1. Surgical debridement compared with conventional nonsurgical management}

\begin{tabular}{lllll}
\hline Outcome or subgroup title & $\begin{array}{l}\text { No. of } \\
\text { studies }\end{array}$ & $\begin{array}{l}\text { No. of } \\
\text { partici- } \\
\text { pants }\end{array}$ & Statistical method & Effect size \\
\hline $\begin{array}{l}1 \text { Number of ulcers completely } \\
\text { healed }\end{array}$ & 1 & 46 & Risk Ratio (M-H, Fixed, 95\% Cl) & $1.21[0.96,1.51]$ \\
\hline 2 Time to complete healing (days) & 1 & 46 & Mean Difference (IV, Fixed, 95\% Cl) & $0.0[0.0,0.0]$ \\
\hline 3 Recurrence rates & 1 & 46 & Risk Ratio (M-H, Fixed, 95\% Cl) & $0.41[0.12,1.35]$ \\
\hline \hline
\end{tabular}

Debridement of diabetic foot ulcers (Review) 


\begin{tabular}{lllll}
\hline Outcome or subgroup title & $\begin{array}{l}\text { No. of } \\
\text { studies }\end{array}$ & $\begin{array}{l}\text { No. of } \\
\text { partici- } \\
\text { pants }\end{array}$ & Statistical method & Effect size \\
\hline $\begin{array}{l}4 \text { Number of complications - Number } \\
\text { of adverse events reported }\end{array}$ & 1 & 46 & Odds Ratio (M-H, Fixed, 95\% Cl) & $0.33[0.03,3.47]$ \\
\hline
\end{tabular}

Analysis 1.1. Comparison 1 Surgical debridement compared with conventional nonsurgical management, Outcome 1 Number of ulcers completely healed.

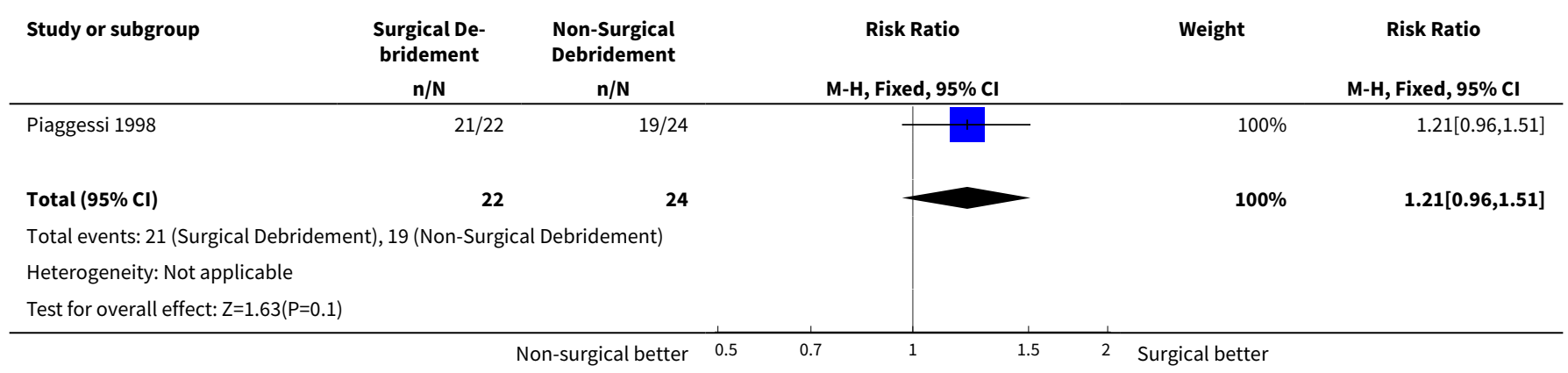

Analysis 1.2. Comparison 1 Surgical debridement compared with conventional nonsurgical management, Outcome 2 Time to complete healing (days).

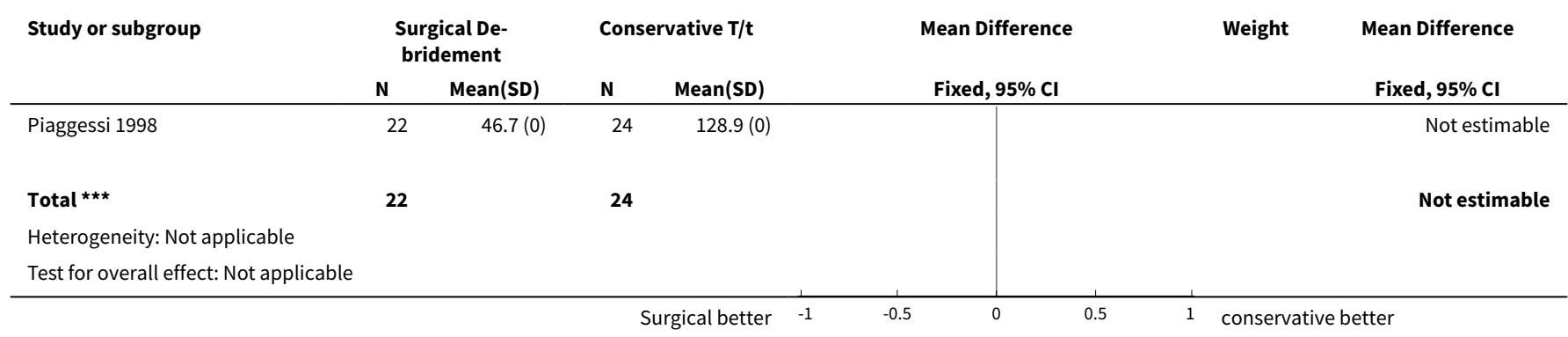

Analysis 1.3. Comparison 1 Surgical debridement compared with conventional nonsurgical management, Outcome 3 Recurrence rates.

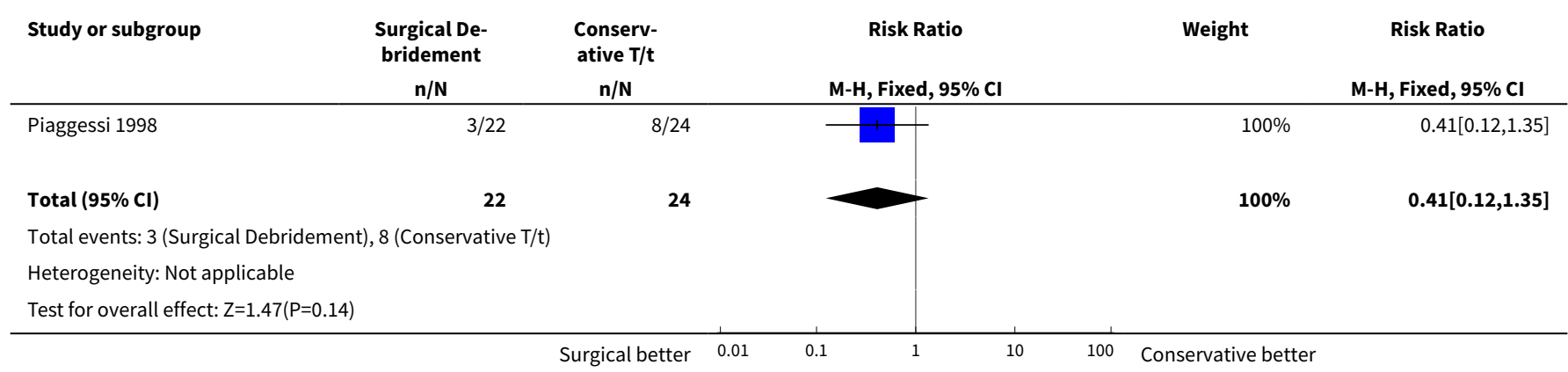


Analysis 1.4. Comparison 1 Surgical debridement compared with conventional nonsurgical management, Outcome 4 Number of complications - Number of adverse events reported.

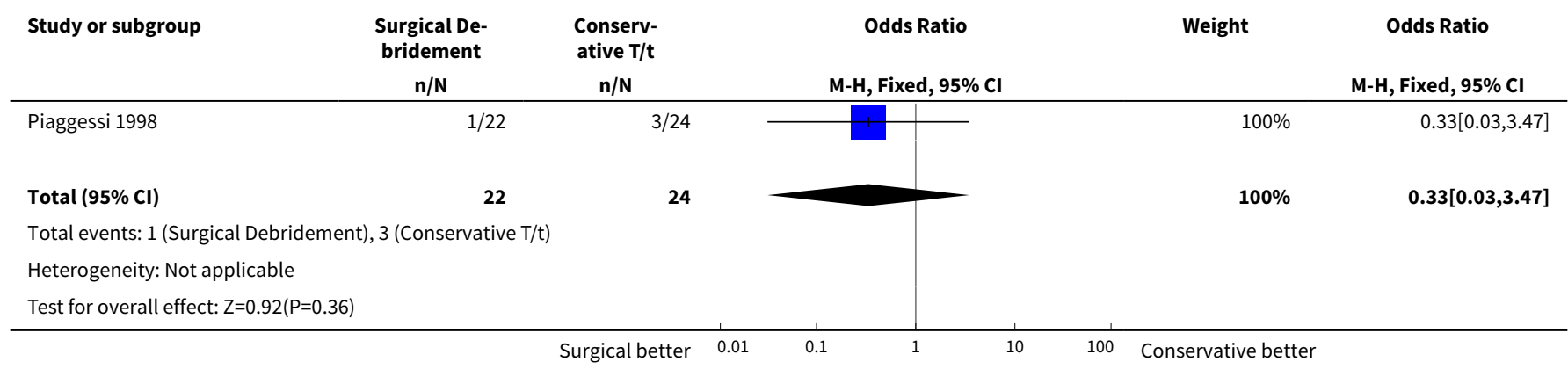

\section{Comparison 2. Larvae compared with Hydrogel}

\begin{tabular}{lllll}
\hline Outcome or subgroup title & $\begin{array}{l}\text { No. of } \\
\text { studies }\end{array}$ & $\begin{array}{l}\text { No. of } \\
\text { partici- } \\
\text { pants }\end{array}$ & Statistical method & Effect size \\
\hline 1 Number of ulcers completely healed & 1 & & Risk Ratio (M-H, Fixed, 95\% Cl) & Totals not selected \\
\hline $\begin{array}{l}2 \text { Reduction of wound area by more } \\
\text { than } 50 \%\end{array}$ & 1 & Risk Ratio (M-H, Fixed, 95\% Cl) & Totals not selected \\
\hline
\end{tabular}

Analysis 2.1. Comparison 2 Larvae compared with Hydrogel, Outcome 1 Number of ulcers completely healed.

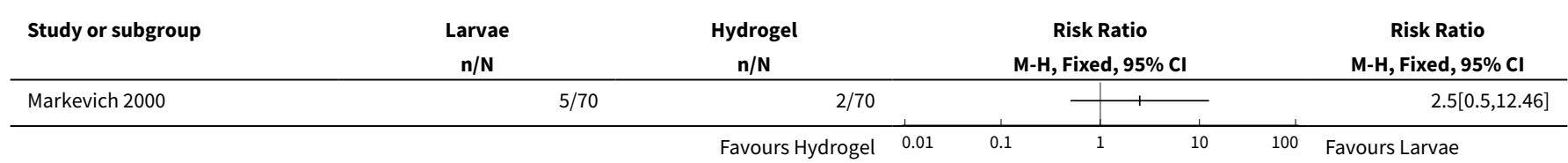

Analysis 2.2. Comparison 2 Larvae compared with Hydrogel, Outcome 2 Reduction of wound area by more than $50 \%$.

\begin{tabular}{|c|c|c|c|c|c|c|}
\hline Study or subgroup & $\begin{array}{l}\text { Larvae } \\
\mathbf{n} / \mathbf{N}\end{array}$ & $\begin{array}{c}\text { Hydrogel } \\
\mathrm{n} / \mathrm{N}\end{array}$ & & & $\begin{array}{l}\text { Ratio } \\
\text { ed, } 95 \% \mathrm{Cl}\end{array}$ & $\begin{array}{c}\text { Risk Ratio } \\
\text { M-H, Fixed, } 95 \% \mathrm{Cl}\end{array}$ \\
\hline Markevich 2000 & $36 / 70$ & $19 / 70$ & & & 1 & $1.89[1.21,2.96]$ \\
\hline
\end{tabular}


Comparison 3. Hydrogel compared with gauze or good wound care (gwc)

\begin{tabular}{llllll}
\hline Outcome or subgroup title & $\begin{array}{l}\text { No. of } \\
\text { studies }\end{array}$ & $\begin{array}{l}\text { No. of } \\
\text { partici- } \\
\text { pants }\end{array}$ & Statistical method & Effect size \\
\hline $\begin{array}{lllll}\text { 1 Number of ulcers completely healed } \\
\text { 2 Number of complications - number of } \\
\text { adverse events reported }\end{array}$ & 3 & 198 & Risk Ratio (M-H, Fixed, 95\% Cl) & $1.84[1.30,2.61]$ \\
\hline 3 Quality of life / increase in pain & 1 & 198 & Risk Ratio (M-H, Fixed, 95\% Cl) & $0.60[0.38,0.95]$ \\
\hline
\end{tabular}

Analysis 3.1. Comparison 3 Hydrogel compared with gauze or good wound care (gwc), Outcome 1 Number of ulcers completely healed.

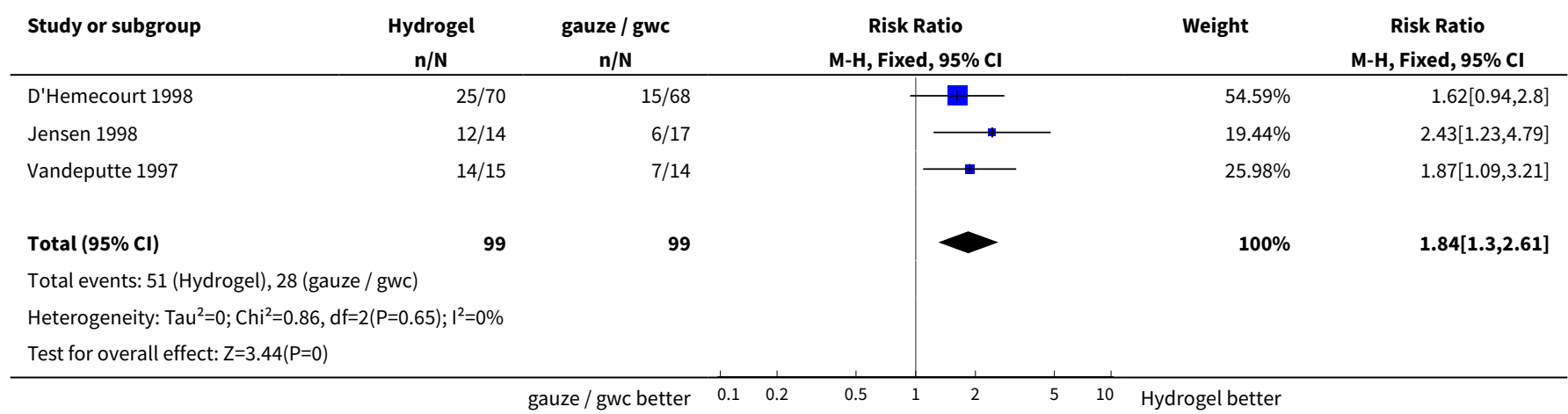

Analysis 3.2. Comparison 3 Hydrogel compared with gauze or good wound care (gwc), Outcome 2 Number of complications - number of adverse events reported.

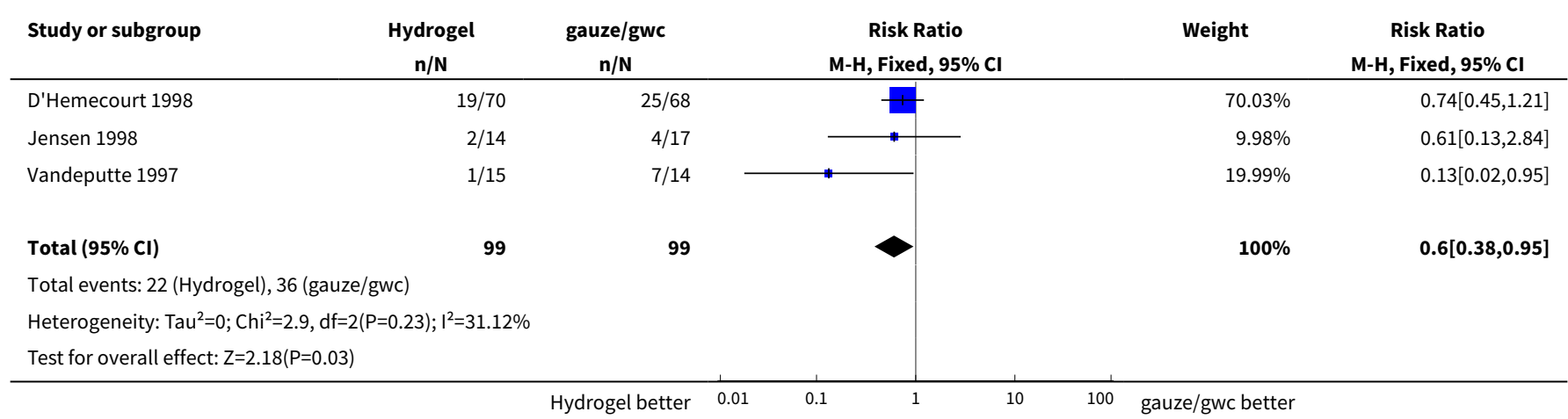


Analysis 3.3. Comparison 3 Hydrogel compared with gauze or good wound care (gwc), Outcome 3 Quality of life / increase in pain.

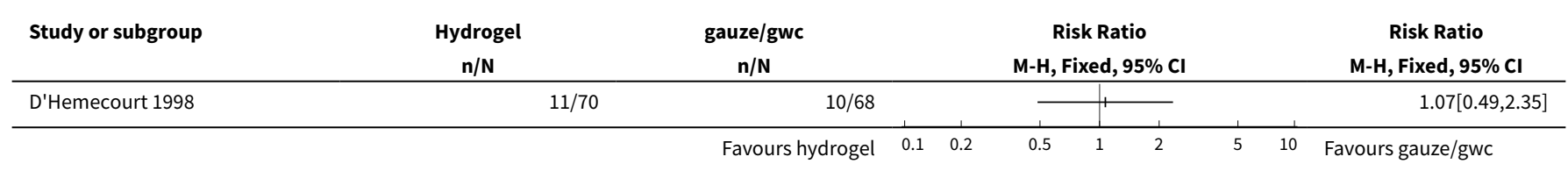

\section{ADDITIONAL TABLES}

\section{Table 1. Methods of debridement}

Debride- Explanation
ment
Method

\begin{tabular}{|c|c|c|c|}
\hline \multicolumn{4}{|l|}{ Mechanical } \\
\hline $\begin{array}{l}\text { Surgical } \\
\text { (scalpel) }\end{array}$ & $\begin{array}{l}\text { The technique is simple, requiring the use of only sterile scissors or } \\
\text { a scalpel, but it does require a certain amount of skill to prevent en- } \\
\text { larging the wound. }\end{array}$ & Quick & $\begin{array}{l}\text { Can make the wound big- } \\
\text { ger }\end{array}$ \\
\hline Wet-to dry & $\begin{array}{l}\text { The wound is soaked in saline to moisten hard material before the } \\
\text { application of a moist gauze pad over the affected area. As the de- } \\
\text { vitalised tissue dries it re-hardens and becomes attached to the } \\
\text { gauze, when the dressing is changed the adhered material is pulled } \\
\text { free. }\end{array}$ & $\begin{array}{l}\text { Allows removal } \\
\text { of hardened } \\
\text { necrosis Inex- } \\
\text { pensive }\end{array}$ & $\begin{array}{l}\text { It is not discriminating } \\
\text { and may remove granu- } \\
\text { lating tissue. It also may } \\
\text { be painful for the patient. }\end{array}$ \\
\hline Bio-Surgery & $\begin{array}{l}\text { Sterile maggots of the green bottle fly Lucilia sericata are placed di- } \\
\text { rectly on to the affected area and held in place by a close net dress- } \\
\text { ing. The larvae have a ferocious appetite for necrotic material while } \\
\text { actively avoiding newly formed healthy tissue. }\end{array}$ & $\begin{array}{l}\text { They discrimi- } \\
\text { nate between } \\
\text { the necrotic and } \\
\text { the granulating } \\
\text { tissue. }\end{array}$ & $\begin{array}{l}\text { There is at present no } \\
\text { conclusive evidence of } \\
\text { effectiveness in foot ul- } \\
\text { cers, there may also be } \\
\text { a reluctance to use this } \\
\text { treatment by patients } \\
\text { and clinicians, there is a } \\
\text { cost implication }\end{array}$ \\
\hline
\end{tabular}

\section{Non-Me-}

chanical -

These treat-

ments are

easy to ap-

ply and have

additional

properties

that may be

beneficial for

wound heal-

ing

\begin{tabular}{|c|c|c|c|}
\hline $\begin{array}{l}\text { Enzyme } \\
\text { Preparations }\end{array}$ & $\begin{array}{l}\text { The only formulation available in the UK contains Streptokinase } \\
\text { and Streptodornase (Varidase Topical }{ }^{\circledR} \text { Wyeth Laboratories). This } \\
\text { enzyme aggressively digests the proteins fibrin, collagen \& elastin, } \\
\text { which are commonly found in the necrotic exudate of a wound. } \\
\text { Other enzymatic preparations include trypsin and collagenase, are } \\
\text { licensed in other countries. }\end{array}$ & $\begin{array}{l}\text { They can be ap- } \\
\text { plied directly on- } \\
\text { to the necrotic } \\
\text { area }\end{array}$ & $\begin{array}{l}\text { Streptokinase can be sys- } \\
\text { temically absorbed and } \\
\text { is therefore contraindi- } \\
\text { cated in patients at risk } \\
\text { of an MI. There is a cost } \\
\text { implication }\end{array}$ \\
\hline
\end{tabular}


Table 1. Methods of debridement (Continued)

Polysaccha- Is supplied as anhydrous porous beads or as a paste. The beads ride beads or are highly hydrophilic and rapidly absorb exudate from a necrotic paste dextranomer polysaccharide necrotic material is removed. sloughy mass. The beads are removed by washing and the trapped

\section{Hydrogels}

\begin{abstract}
These gels are biologically inert and have significant water content. They complement the body's natural debriding process by providing a moist environment, which promotes autolysis, while still act-
\end{abstract} ing to preserve living healthy tissue. (Bradley 1999)
They can be applied directly onto the necrotic area. Minimal level of skill required.

They can be applied to a wound at any stage, as they promote moist wound healing they will do the wound no harm. Minimal level of skill required.
They can be seen as the minimum level of debridement for a sloughy wound. If not masked properly they may macerate the surrounding tissue

Table 2. Inclusion \& exclusion criteria for included trials

\begin{tabular}{ll}
\hline Trial Author & Inclusion Criteria \\
\hline D'Hemecourt & $\begin{array}{l}\text { 19 years or older, type } 1 \text { or type } 2 \text { diabetes, at least } 1 \text { full thickness ul- } \\
\text { (1998): written }\end{array}$ \\
$\begin{array}{l}\text { cer (stage } 3 \text { or } 4), \text { ulcer present } 8 \text { weeks prior to study, } 1 \mathrm{~cm}^{2}-10 \mathrm{~cm}^{2} \\
\text { post debridement }, \mathrm{TcpO} 2>/ 30 \mathrm{mmHg}, \text { chronic diabetic ulcer of low- } \\
\text { er extremity. }\end{array}$
\end{tabular}

\section{Exclusion Criteria}

Osteomyelitis, outside $1 \mathrm{~cm}^{2}-10 \mathrm{~cm}^{2}$ range, patient has more than $3 \mathrm{ul}$ cers, cause of ulcer was not diabetes e.g. electrical, chemical or radiation, patients with cancer, concomitant medication to affect wound healing, women who were pregnant, nursing or of child bearing potential.

Jensen (1997): written consent needed
Diabetic foot ulcer of at least $1 \mathrm{~cm}$ diameter, no evidence of infection in ulcer or peri-wound tissue, Wagner grade 2 ulcer - full thickness into subcutaneous tissue, but not involving tendon joint capsule or bone, documented blood supply consistent with the ability to heal (palpable pulses, non-invasive vascular study), willingness to comply with protocol.
No exclusion criteria listed

Noxclusion criteria listed 
Table 3. Trials reporting baseline wound statistics (Continued)

\section{APPENDICES}

\section{Appendix 1. Search strategy for the third update 2009}

For this third update the following databases were searched:

- Cochrane Wounds Group Specialised Register (Searched 23/6/09)

- The Cochrane Central Register of Controlled Trials (CENTRAL) - The Cochrane Library 2009, Issue 2

- Ovid MEDLINE - 1950 to June Week 32009

- Ovid EMBASE - 1980 to 2009 Week 25

- Ovid CINAHL - 1982 to June Week 32009

The search strategies for Ovid MEDLINE, Ovid EMBASE and EBSCO CINAHL can be found in Appendix 2, Appendix 3 and Appendix 4 respectively. The Ovid MEDLINE search was combined with the Cochrane Highly Sensitive Search Strategy for identifying randomised trials in MEDLINE: sensitivity- and precision-maximizing version (2008 revision); Ovid format. The EMBASE and CINAHL searches were combined with the trial filters developed by the Scottish Intercollegiate Guidelines Network (SIGN). No date or language restrictions were applied.

\section{Appendix 2. Ovid MEDLINE search strategy}

1 exp Debridement/

2 (debrid\$ or slough\$ or deslough\$).ti,ab.

3 exp Larva/

4 (larva\$ or maggot\$ or biosurgery or bio-surgery).ti,ab.

5 (wound\$ adj (irrigat\$ or cleanse\$)).ti,ab.

6 whirlpool.ti,ab.

7 (collagenase $\$$ or fibrinolytic\$ or proteolytic\$ or trypsin or streptokinase or streptodornase or varidase).ti,ab.

8 exp Papain/

9 papain.ti,ab.

10 (hypochlorite or hydrogen peroxide).ti,ab.

11 (malic acid or benzoid acid or salicylic acid or propylene glycol).ti,ab.

12 dakin solution.ti,ab.

13 (dextranomer\$ or cadexomer or xerogel or eusol or debrisan).ti,ab.

14 (polysaccharide adj (bead\$ or paste\$)).ti,ab.

15 (iodoflex or iodosorb).ti,ab.

16 (((gauze or adherent or absorbent or tulle or polysaccaride or alginate or foam or hydrofibre or hydrofiber) adj dressing\$) or saline gauze or hydrocolloid\$ or granuflex or tegasorb or aquacel or hydrocoll or combiderm or duoderm).ti,ab.

17 ((wet or dry) adj2 dressing\$).ti,ab.

18 exp Honey/

19 honey\$.ti,ab.

20 exp Hydrogel/

21 (hydrogel\$ or intrasite gel or intrasitgel or sterigel or granugel or nugel or purilon or vigilon).ti,ab.

22 exp Zinc Oxide/

23 zinc oxide.ti,ab.

24 or/1-23

25 exp Diabetic Foot/

$26 \exp$ Foot Ulcer/

27 (diabet\$ adj3 ulcer\$).ti,ab.

28 (diabet\$ adj3 (foot or feet)).ti,ab.

29 (diabet\$ adj3 wound\$).ti,ab. 
30 or $/ 25-29$

3124 and 30

\section{Appendix 3. Ovid EMBASE search strategy}

1 exp Debridement/

2 (debrid\$ or slough\$ or deslough\$).ti,ab.

3 exp Maggot Therapy/

4 (larva\$ or maggot\$ or biosurgery or bio-surgery).ti,ab.

5 (wound\$ adj (irrigat\$ or cleanse\$)).ti,ab.

6 whirlpool.ti,ab.

7 (collagenase\$ or fibrinolytic\$ or proteolytic\$ or trypsin or streptokinase or streptodornase or varidase).ti,ab.

8 exp Papain/

9 papain.ti,ab.

10 (hypochlorite or hydrogen peroxide).ti,ab.

11 (malic acid or benzoid acid or salicylic acid or propylene glycol).ti,ab.

12 dakin solution.ti,ab.

13 (dextranomer\$ or cadexomer or xerogel or eusol or debrisan).ti,ab.

14 (polysaccharide adj (bead\$ or paste\$)).ti,ab.

15 (iodoflex or iodosorb).ti,ab.

16 (((gauze or adherent or absorbent or tulle or polysaccaride or alginate or foam or hydrofibre or hydrofiber) adj dressing\$) or saline gauze or hydrocolloid\$ or granuflex or tegasorb or aquacel or hydrocoll or combiderm or duoderm).ti,ab. (940)

17 "wet-to-dry dressings".ti,ab.

18 exp Honey/

19 honey\$.ti,ab.

20 exp Hydrogel Dressing/

21 (hydrogel\$ or intrasite gel or intrasitgel or sterigel or granugel or nugel or purilon or vigilon).ti,ab.

22 exp Zinc Oxide/

23 zinc oxide.ti,ab.

24 or/1-23

25 exp Foot Ulcer/

26 exp Diabetic Foot/

27 (diabet\$ adj3 ulcer\$).ti,ab.

28 (diabet\$ adj3 (foot or feet)).ti,ab.

29 (diabet\$ adj3 wound\$).ti,ab.

30 or $/ 25-29$

3124 and 30

\section{Appendix 4. EBSCO CINAHL search strategy}

\section{S30 S23 and S29}

S29 S24 or S25 or S26 or S27 or S28

S28 TI diabet $^{\star}$ N3 wound* or AB diabet* N3 wound*

S27 TI (diabet* N3 foot or diabet ${ }^{\star}$ N3 feet) or AB (diabet* N3 foot or diabet* N3 feet)

S26 TI diabet* N3 ulcer* or AB diabet* N3 ulcer ${ }^{\star}$

S25 (MH "Foot Ulcer+")

S24 (MH "Diabetic Foot")

$\mathrm{S} 23 \mathrm{~S} 1$ or $\mathrm{S} 2$ or $\mathrm{S} 3$ or $\mathrm{S} 4$ or $\mathrm{S} 5$ or $\mathrm{S} 6$ or $\mathrm{S} 7$ or $\mathrm{S} 8$ or $\mathrm{S} 9$ or $\mathrm{S} 10$ or $\mathrm{S} 11$ or $\mathrm{S} 12$ or $\mathrm{S} 13$ or $\mathrm{S} 14$ or $\mathrm{S} 15$ or $\mathrm{S} 16$ or $\mathrm{S} 17$ or $\mathrm{S} 18$ or $\mathrm{S} 19$ or $\mathrm{S} 20$ or $\mathrm{S} 21$ or $\mathrm{S} 22$

S22 TI zinc oxide or AB zinc oxide

S21 (MH "Zinc Oxide")

S20 TI (hydrogel ${ }^{*}$ or intrasite gel or intrasitgel or sterigel or granugel or nugel or purilon or vigilon) or AB (hydrogel ${ }^{\star}$ or intrasite gel or intrasitgel or sterigel or granugel or nugel or purilon or vigilon)

S19 (MH "Hydrogel Dressings")

S18 TI honey or AB honey

S17 (MH "Honey")

S16 TI wet-to-dry dressings or AB wet-to-dry dressings

S15 TI (dressing* or gauze or adherent or absorbent or tulle or polysaccaride or alginate or foam or hydrofibre or hydrofiber or hydrocolloid * or granuflex or tegasorb or aquacel or hydrocoll ${ }^{\star}$ or combiderm or duoderm)or AB (dressing ${ }^{\star}$ or gauze or adherent or absorbent or tulle or polysaccaride or alginate or foam or hydrofibre or hydrofiber or hydrocolloid or granuflex or tegasorb or aquacel or hydrocoll ${ }^{\star}$ or combiderm or duoderm)

S14 TI ( iodoflex or iodosorb ) or AB (iodoflex or iodosorb )

S13 TI (polysaccharide bead* or polysaccharide paste) or AB (polysaccharide bead* or polysaccharide paste)

S12 TI (dextranomer* or cadexomer or xerogel or eusol or debrisan) or AB (dextranomer* or cadexomer or xerogel or eusol or debrisan) 
S11 TI dakin solution or AB dakin solution

S10 TI (malic acid or benzoid acid or salicylic acid or propylene glycol) or AB (malic acid or benzoid acid or salicylic acid or propylene glycol)

S9 $\mathrm{TI}$ (hypochlorite or hydrogen peroxide) or $\mathrm{AB}$ (hypochlorite or hydrogen peroxide)

S8 TI whirlpool or AB whirlpool

$\mathrm{S} 7 \mathrm{TI}$ (wound irrigat* or wound cleans ${ }^{\star}$ ) or $\mathrm{AB}$ (wound irrigat* or wound cleans ${ }^{\star}$ )

S6 TI papain or AB papain

S5 TI (collagenase* or fibrinolytic ${ }^{\star}$ or proteolytic* or trypsin or streptokinase or streptodornase or varidase) or AB (collagenase* or fibrinolytic* or proteolytic ${ }^{\star}$ ortrypsin or streptokinase or streptodornase or varidase)

S4 TI (larva* or maggot* or biosurgery or bio-surgery) or AB (larva* or maggot* or biosurgery or bio-surgery)

S3 (MH "Larval Therapy")

S2 TI (debrid* or slough ${ }^{\star}$ or deslough ${ }^{\star}$ ) or AB (debrid* or slough ${ }^{\star}$ or deslough ${ }^{\star}$ )

S1 (MH "Debridement")

\section{FEE D B A C K}

\section{Inclusion of Markevich et al 2000, 13 February 2009}

\section{Summary}

Feedback submitted by Ronald Sherman - as follows:

My concerns center around the inclusion of Markevich's study of maggot therapy for debriding diabetic foot ulcers, which really does not belong in a Cochrane review claiming to examine the effect of diabetic foot ulcer debridement on wound healing.

Let us closely examine Markevich's study and the misleading or inaccurate statements in Edwards' review:

Point 1:

Most egregious is the suggestion that Markevich's study was designed to investigate the effect of maggot therapy on wound healing. Markewich's paper clearly describes the study period as being only 10 days. No wound care professional would seriously believe that a 10-day study was designed to measure wound closure. For this reason alone it does not belong in this review of "wound healing after debridement" studies. All other studies in this analysis clearly measured healing after 10-26 weeks, as a specific study endpoint. It is inappropriate and irresponsible for Edwards to point to Markevich's 10-day study as evidence that maggot debridement results in "no statistically significant difference" in the proportion of ulcers completely healed.

Point 2:

What does Edwards have to say about the outcomes which Markevich's study was designed to measure? What does Edwards' review state about Markewich's primary results? Markewich's primary results were that, within 10 days, $60 \%$ of maggot-treated wounds were debrided and at least $50 \%$ covered by granulation tissue, vs $33.4 \%$ of control wounds $(p<0.001)$. Also by day $10,51 \%$ of the maggot-treated wounds had decreased in size by at least $50 \%$, compared to only $27 \%$ of the control wounds $(p<0.05)$. Edwards mentions nothing about these primary findings. In the detailed review of all other studies included in Edwards' paper, primary and secondary outcomes are discussed under headings so labelled. But in the discussion of Markewich's study, Edwards omitted a "primary outcomes" heading, and avoided any mention of the primary outcome measures altogether. The only finding for this study that was mentioned was that $5 / 70$ (7\%) maggottreated wounds healed, vs 2 of $70(3 \%)$ control wounds; and that this was not a significant difference. The impression is that this is the primary outcome measure; the primary result of the Markevich's study. This is not just my impression, but the interpretation of other authors who have since cited Edwards' paper as the source for their incorrect statement that failure to improve wound healing was the primary outcome of Markevich's study. What does Edwards have to say about the fact that this measurement was on day 10 ? Edwards states that "it is unclear from the abstract how long it took to achieve wound healing." It is very clear to me that the assessment of wound healing was made at day 10, as were the other findings in the report (despite the fact that English is not the primary language of the study's author). But if the results were "not clear" to me, I certainly would not have included Markevich's study abstract (the full study has never been published) in a review about wound healing, in which every other study clearly measured healing endpoints at 10-26 weeks!

Point 3:

What are some other examples of inappropriately strong and erroneous statements? As I have noted, Markevich's study demonstrated the efficacy of maggot therapy for debridement, if not wound healing. Other controlled clinical studies published after 2000 have similarly demonstrated the efficacy and safety of maggot therapy for debridement of diabetic foot ulcers (Sherman, 2003), pressure ulcers (Sherman, 2002), venous stasis ulcers (Wayman et al, 2000) and other foot and leg wounds. Yet, Edwards states in Table 1 ("Methods of Debridement") that one of the disadvantages of maggot therapy is that "there is at present no conclusive evidence of [debridement] effectiveness in foot ulcers." That conclusion was not well founded in 2002, and clearly is not defendable now.

Point 4:

In the abstract (Main Results), Edwards states that "Surgical debridement and larval therapy showed no significant benefit over standard treatment and hydrogel respectively in these small trials." Again, this study of larval therapy (here described as "small," but in fact one of the largest studies in Edward's review) DID show significant benefit over standard treatment as a method of debridement. Concluding that this 10-day study demonstrates no benefit in wound closure rate from maggot therapy is a serious misinterpretation of Markevich's study. 


\section{Reply}

Reply from Jude Edwards, review author - as follows:

Thank you for your comment which we have considered carefully, please find below our point by point responses to the issues raised:

The Cochrane review, 'Debridement of diabetic foot ulcers', follows the principles of all Cochrane systematic reviews in that it aims to provide a summary of the best available evidence. Cochrane reviews include data from randomised controlled trials; when properly randomised, they do not suffer from selection bias and so provide the best estimates of treatment effects.

Point 1:

Firstly, the primary study authors' objectives for the primary study are largely irrelevant when conducting a systematic review, provided the primary study meets all the pre-specified eligibility criteria. In other words, original authors' study objectives do not contribute to eligibility or selection decisions. We cannot from the abstract judge quite what the objective was in the Markevich study but since they randomised a debriding agent and measured wound healing in people with diabetic foot ulcers, we are happy to include it in this review. The eligibility criteria for this review, which were pre-specified in the protocol before the review was conducted, stated that studies which measured the rate of change of wound size were eligible for inclusion, not just studies which measured time to complete healing. By these prespecified criteria, the Markevich study should be included, though we agree, 10 days is insufficient time to observe complete wound healing.

Point 2:

We are extremely grateful to you for bringing to our attention the omission of the healing rate data from the review. This was an accidental oversight which we have now corrected in the updated review. It is correct, however, that the review also presents the complete healing findings as this was also prespecified in the protocol.

Point 3:

This review has recently been updated and the comprehensive searches are current to June 2009. We identified no other RCTs of larval therapy for diabetic foot ulcer, and we have a policy of not including quasi randomised or non-randomised controlled studies in the presence of RCTs since they are far more susceptible to selection bias. We cannot include trials that relate to other types of wounds in a review of treatments for diabetic foot ulcers however another Cochrane review is considering the same question in people with venous leg ulcers.

Point 4:

We have amended the abstract, results and conclusions of the review to reflect the inclusion of the data on reduction in wound area.

Thank you for your observations which have undoubtedly helped improve the quality of this review.

\section{Contributors}

Ronald A. Sherman, MD, MSc, DTM\&H (London)

Executive Director and Chairman of the Board, BioTherapeutics, Education \& Research Foundation.

Laboratory Director and Co-Founder, Monarch Labs, LLC.

HIV Clinic Physician, Orange County Health Care Agency. Santa Ana, CA. USA.

Jude Edwards

Strength of evidence provided by Markevich et al 2000, 24 January 2010

\section{Summary}

Comments from: Dr Heike Heuer on the consideration to include recently published trials (VenUS I and VenUS II). In addition the consistency in the conclusions regarding the strength of evidence contributed by the Markevich trail in the abstract compared with the text of the review. As follows:

\section{Initial comment from: Dr Heike Heuer}

We have seen your papers on maggot therapy (leg ulcers), published last year and we were, as everybody using medicinal larvae, surprised on the results you published. Even though, we are strong followers of evidence based medical treatments and your work gives evidence. Although and as many others we hoped to have more evidence for wound healing, we accept the finding on evidence for debridement only.

Today we found the review cited in the title of Dr. Edwards and Dr. Stapley (foot ulcer). This review claims to up-to-date to October 2009. As you may see in the mail we foreward to your hands, we are somewhat surprise since we read it.

To have reliable information available is most important for any therapy including maggot therapy. Do you believe that there is a significant difference between leg and foot ulcers regarding maggot therapy. In this case we are wondering why Dr. Edwards did not even mention the results published by VenUS I and VenUS II, as these give evidence where the study of Markevich 2000 is judged by Edwards as unclear in all points of possible bias. In 
addition Edwards wrote that Markevich could not even be contacted for further questions.

As the full paper costs the reader about $\$ 30$, most interested readers will read only the free abstract. In that abstract the authors conclusion is: ... and larval therapy resulted in significantly greater reduction in wound area than hydrogel.

Could you pls. commend and help us understanding this confusion.

\section{Further response from Dr Heike Heuer}

Thank you very much for your answer and your kind mail. I do accept when foot and leg is argued to be different populations of diabetic ulcers. Although I believe, that with regards to debriding both will behave more or less similar.

As there are no new facts from studies on maggot debridement of diabetic foot ulcers, the results of Markevich (2000) are summed up to a different conclusion. The study of Markevich is marked with lots of possible bias in the full text but very much optimistic in the abstract. In fact, the major different in the first and in the last COCHRANE is only one RTC study on hydrogels. There are no new data on maggots available but a different view on these (in the abstract).

\section{Reply}

\section{Response to initial comment from the Cochrane Wounds Group Managing Editor: Sally Bell-Syer}

The Cochrane review you have cited by Edwards J, Stapley S. Debridement of diabetic foot ulcers, is indeed recently updated and aims to assess the effects of debridement interventions on the healing of foot ulcers in people with diabetes. The population of interest for this review are people with diabetes who have a foot ulcer and the study you refer to - Markevich (2000) - states that they included people with diabetic neuropathic foot lesions.

In addition you have highlighted two recent papers published in the BMJ which report on a randomised controlled trial which compared the clinical effectiveness of larval therapy with a standard debridement technique (hydrogel) for sloughy or necrotic leg ulcers. The participants eligible for inclusion in this trial had venous or mixed venous and arterial leg ulcers.

Essentially these are two different populations. The review by Edwards would not consider the RCT conducted in people with venous leg ulcers as eligible for inclusion as their population of interest is people with diabetes who have a foot ulcer. However you may be interested to know that there is an ongoing Cochrane review of 'Debridement for venous leg ulcers' which is at draft protocol stage and this review will consider the RCT by Dumville et al which has participants with venous leg ulcers.

I hope this explain how the Cochrane reviews are dealing with these two distinct populations. If you have any further queries please let me know.

\section{Further response from the Cochrane Wounds Group Managing Editor: Sally Bell-Syer}

Thank you for your response and further comments of clarification.

As you are aware the Markevich study is in abstract form only and whilst we have contacted the author in an effort to obtain a full trial report and more information we have received no reply. You quite correctly point out that the message given in the abstract "One small trial suggested that larvae resulted in a more than $50 \%$ reduction in wound area compared with hydrogel" is more positive than the message given by the results presented in the text of the review.

We are very grateful that you have taken the time to contact us and we will now revisit the abstract of this review and revise the text to ensure that the message is more in line with the results that were available to the review authors and are presented in the text of the review.

This feedback is very important to us, whilst we do spend a great deal of time in an effort to ensure that all aspects of the review are accurate and consistent the observations and comments of our peers are valuable. Thank you for taking the time to contact us and we will amend the review in time for the next submission to the Cochrane Library.

\section{Contributors}

Dr Heike Heuer. Agiltera GmbH\&Co.KG, Geschäftsführung

Sally Bell-Syer, Cochrane Wounds Group Managing Editor

\section{WHAT'S NEW}

\begin{tabular}{lll}
\hline Date & Event & Description \\
\hline 5 December 2011 & Amended & Amended labels on graph axes, Analysis 2.2. \\
\hline
\end{tabular}




\section{HISTORY}

Protocol first published: Issue 2, 2002

Review first published: Issue 4, 2002

\begin{tabular}{lll}
\hline Date & Event & Description \\
\hline 23 September 2011 & New search has been performed & $\begin{array}{l}\text { Fourth update, new search, 1 study excluded (Abbruzzese 2009) } \\
\text { and 3 studies awaiting assessment as further information re- } \\
\text { quested (Biliaieva 2009; Cardinal 2009; Singh 2006). }\end{array}$ \\
\hline
\end{tabular}

$\begin{array}{lll}17 \text { February } 2010 \quad \text { Feedback has been incorporated } & \begin{array}{l}\text { Slight adjustment to the wording of the conclusions in the ab- } \\ \text { stract and plain language summary to ensure consistency with } \\ \text { text in main review. }\end{array}\end{array}$

\begin{tabular}{lll}
\hline 5 November 2009 & $\begin{array}{l}\text { New citation required but conclusions } \\
\text { have not changed }\end{array}$ & New author joined review team. \\
\hline 5 November 2009 & Feedback has been incorporated & $\begin{array}{l}\text { Feedback received concerning an included trial and author re- } \\
\text { sponse added. }\end{array}$ \\
\hline
\end{tabular}

19 October $2009 \quad$ New search has been performed Third update. New author joined review team, new search, six
studies added to the table of excluded studies, risk of bias table completed.

\begin{tabular}{lll}
\hline 11 August 2009 & Amended & Contact details updated. \\
\hline 23 April 2008 & Amended & Converted to new review format. \\
\hline 7 May 2007 & New search has been performed & $\begin{array}{l}\text { Second update. For this second update, new searches were car- } \\
\text { ried out in June 2007. Eight citations were identified, of which } \\
\text { one (Whalley 2001) was included. One study (Dolnychuck 2001), } \\
\text { which was awaiting assessment, has now been excluded along } \\
\text { with two other studies (Jude 2004; Varma 2006). The review au- } \\
\text { thors conclusions remain unchanged. }\end{array}$ \\
\hline
\end{tabular}

22 August $2005 \quad$ New search has been performed

For this first update, new searches were carried out in May 2005. Eight studies were identified, of which four were excluded. Three studies (Capillas 2002, Dolnychuck 200, Whalley 2001) are awaiting assessment. One duplicate publication has been added as a secondary reference. One study (Mulder 1994b), which was awaiting assessment in the original review, has now been excluded. The reviewers conclusions remain unchanged.

25 June $2002 \quad \begin{aligned} & \text { New citation required and conclusions } \\ & \text { have changed }\end{aligned}$

\section{CONTRIBUTIONS OF AUTHORS}

Jude Edwards: initiated the review, performed the data extraction, analysed the data, wrote the report and updated the review. Is the guarantor for the review.

Sally Stapley: collaborated on the third update, assessed the search results, undertook the risk of bias assessment and updated the review.

\section{Contributions of editorial base:}

Nicky Cullum: edited the review, advised on methodology, interpretation and review content. Approved the final review and review update prior to submission. 
Sally Bell-Syer: coordinated the editorial process. Advised on methodology, interpretation and content. Edited and copy edited the review and the updated review. Coordinated and added the feedback.

Ruth Foxlee: designed the search strategy, ran the searches and edited the search methods section for the update.

\section{DECLARATIONS OF INTEREST}

None known.

\section{SOURCES OF SUPPORT}

\section{Internal sources}

- Diabetes Centre, York District Hospital, York, UK.

- Department of Health Sciences, University of York, York, UK.

\section{External sources}

- No sources of support supplied

\section{INDEX TERMS}

\section{Medical Subject Headings (MeSH)}

Bandages; Combined Modality Therapy; Debridement [ ${ }^{*}$ methods]; Diabetic Foot [surgery] [ ${ }^{\star}$ therapy]; Hydrogels [ ${ }^{\star}$ therapeutic use]; Larva; Randomized Controlled Trials as Topic; Wound Healing

\section{MeSH check words}

Animals; Humans 